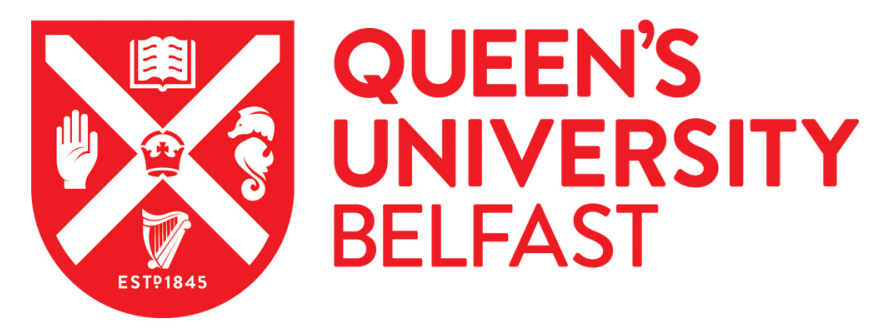

\title{
Phosphorus speciation and fertiliser performance characteristics: a comparison of waste recovered struvites from global sources
}

Hall, R., Boisen Staal, L., Macintosh, K., McGrath, J., Bailey, J., Black, L., Nielsen, U. G., Reitzel, K., \& Williams, P. (2020). Phosphorus speciation and fertiliser performance characteristics: a comparison of waste recovered struvites from global sources. Geoderma, 362, [114096]. https://doi.org/10.1016/j.geoderma.2019.114096

\section{Published in:}

Geoderma

\section{Document Version:}

Peer reviewed version

Queen's University Belfast - Research Portal:

Link to publication record in Queen's University Belfast Research Portal

\section{Publisher rights}

Copyright 2019 Elsevier Ltd.

This manuscript is distributed under a Creative Commons Attribution-NonCommercial-NoDerivs License

(https://creativecommons.org/licenses/by-nc-nd/4.0/), which permits distribution and reproduction for non-commercial purposes, provided the author and source are cited.

\section{General rights}

Copyright for the publications made accessible via the Queen's University Belfast Research Portal is retained by the author(s) and / or other copyright owners and it is a condition of accessing these publications that users recognise and abide by the legal requirements associated with these rights.

Take down policy

The Research Portal is Queen's institutional repository that provides access to Queen's research output. Every effort has been made to ensure that content in the Research Portal does not infringe any person's rights, or applicable UK laws. If you discover content in the Research Portal that you believe breaches copyright or violates any law, please contact openaccess@qub.ac.uk. 


\section{Phosphorus speciation and fertiliser performance characteristics: a}

\section{2 comparison of waste recovered struvites from global sources}

3 Rebecca L. Hall, ${ }^{\text {a, b, }} \S$ Line Boisen Staal, ${ }^{c,}$ Katrina A. Macintosh, ${ }^{\text {a,b }}$ John W. McGrath, ${ }^{\text {a,b John }}$ Bailey, ${ }^{\mathrm{e}}$ Lisa Black, ${ }^{\mathrm{f}}$ Ulla Gro Nielsen, ${ }^{\mathrm{d}}$ Kasper Reitzel, ${ }^{\mathrm{b}^{*}}$ and Paul N. Williams, ${ }^{\mathrm{a},{ }^{*}}$

6 a Institute for Global Food Security, Queen's University Belfast, David Keir Building, Malone

7 Road, Belfast BT9 5BN, Northern Ireland, United Kingdom

8 bSchool of Biological Sciences, 19 Chlorine Gardens, Queen's University Belfast, Belfast, BT9

9 5DL, United Kingdom

$10{ }^{\mathrm{c}}$ Department of Biology, University of Southern Denmark, Campusvej 55, DK-5230 Odense M,

11 Denmark

$12{ }^{\mathrm{d}}$ Department of Physics, Chemistry and Pharmacy, University of Southern Denmark, Campusvej 13 55, DK-5230 Odense M, Denmark

14 e Agri-Food and Biosciences Institute, 18a Newforge Lane, Belfast, BT9 5PX

$15{ }^{\mathrm{f}}$ Agri-Food and Biosciences Institute, 50 Houston Road, Crossnacreevy, Belfast, BT6 9SH

18 * Corresponding author. Email p.williams@qub.ac.uk, phone number: 0289097 6539; Email

19 Reitzel@biology.sdu.dk, 65542774

$20 \S$ These authors contributed equally 


\section{Graphic Abstract}

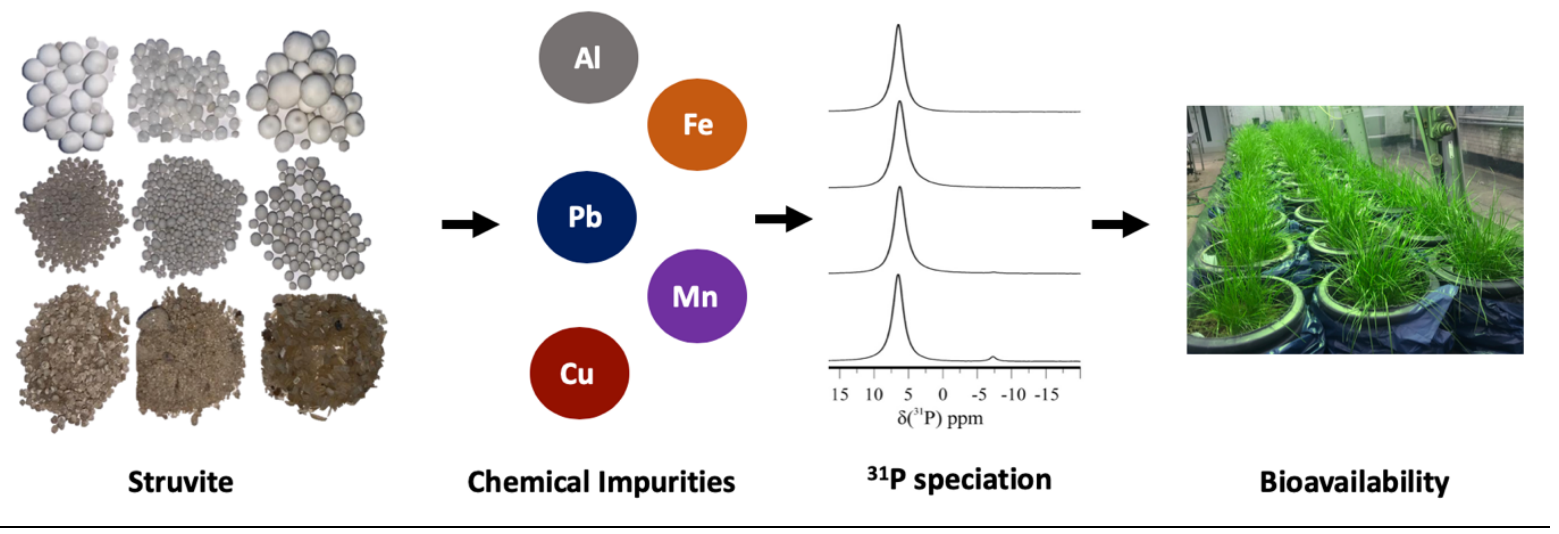

$31 \quad$ Abstract

32 Our immediate and future food security agenda requires sustainable phosphorus $(\mathrm{P})$ management, 33 and recovered $\mathrm{P}$ products such a struvite form part of the solution. Waste recovered struvite is 34 generated from different waste streams and precipitation technologies. In this study, we compare $\mathrm{P}$ speciation and bioavailability of nine struvite products with traditional/granulated chemical fertilisers to investigate performance characteristics across soil types in the Irish ecoregion.

37 Elemental-analysis/P-speciation of the struvites was examined by ICP-OES, ${ }^{31} \mathrm{P}$ solid state NMR, PXRD and P-solubility tests. The fertiliser dose effect and bioavailability of the different struvite products were tested in 4-week and 3-month rhizotron experiments with Lolium perenne. In addition to calculating plant-P offtake, bioavailability was assessed by Olsen-P and Diffusive-

41 Gradients-in-Thin-Films (DGT). The struvites differed markedly in colour/appearance, texture, metal content and solubility. Struvites all had similar P-speciation, but minor impurity phases were detected. There was no significant difference between the struvite samples and triple-super-

44 phosphate (TSP) with respect to either plant growth performance or P-bioavailability. The struvite 
products are produced from different wastewater streams/processes, yet possess a uniformity in overall fertilising performance within our experiments. Encouragingly, no appreciable agronomic

47 difference in terms of yield was observed between the struvite and chemical fertilisers, which 48 provides further evidence in support of struvite as a sustainable alternative to mined rock49 phosphate derived products. Importantly the struvite samples analysed within this study contained 50 both significantly fewer impurities than TSP and lower concentrations of toxic metals such as cadmium.

53 Keywords: Phosphorus, Struvite, X-ray diffraction analysis, Chemical analysis, Spectroscopy,

54 inductively coupled plasma methods.

\section{Abbreviations}

57 DGT diffusive gradients in thin films

$58{ }^{\mathrm{P}} \mathrm{C}_{\text {DGT }}$ Phosphorus concentration from DGT

59 ICP-OES inductively coupled plasma optical emission spectroscopy

60 MAP mono-ammonium phosphate

61 MAS magic angle spinning

62 SSNMR solid state nuclear magnetic resonance

$63 \quad \mathrm{P} \quad$ phosphorus

64 ppm parts per million

65 PXRD powder X-ray diffraction

66 TSP triple superphosphate

67 MAP mono-ammonium phosphate

68 XIA Xiamen 
69 CGS Crystal Green $1.5 \mathrm{~mm}$

70 CGL Crystal Green 3mm

71 AAS Aaby small

72 AAM Aaby medium

73 AAL Aaby large

74 HER Herning

75 HEL Helsingør

76 BER BerlinerPflanzeTM

77

78 
80 Phosphorus (P) is a limited and life-essential element (Cordell and White 2011). P capture as struvite $\left(\mathrm{MgNH}_{4} \mathrm{PO}_{4} \cdot 6 \mathrm{H}_{2} \mathrm{O}\right)$ at wastewater treatment plants provides a sustainable recovery method and aims to protect water quality (Desmidt et al. 2015, Mayer et al. 2016). Waste recovered struvite production has been optimised via a handful of patented precipitation technologies developed principally for application in municipal wastewater (Desmidt et al. 2015). Although struvite precipitation from dairy, urine, swine manure, and semiconductor wastes is now also practised ( $\mathrm{Li}$ et al. 2019), struvite is considered to be a slow-release $\mathrm{P}$ fertiliser, which means that it has a delayed dissolution in soil. This kinetic characteristic has agronomic advantages, principally because $\mathrm{P}$ can be released to the soil porewater throughout the growing season (Talboys et al. 2016). Waste recovered struvite has thus been shown to be an effective soil additive for several crops, with similar yields being reported when compared with traditional inorganic $\mathrm{P}$ fertiliser [triple-super-phosphate (TSP)] (Ahmed et al. 2018, Li et al. 2019). Although published data on the performance of waste recovered P fertilisers is increasing (Johnston and Richards 2003; Ali et al., 2005), the different chemical behaviours of struvite, particularly across differing soil 94 types is less well understood (Symanska et al., 2019).

Several factors impact on the bioavailability of struvite. The positive effect of struvite on aboveground biomass has been well-established for low-pH soils with high proton $/ \mathrm{H}^{+}$concentrations (Hilt et al. 2016; Degryse et al. 2017), with the $\mathrm{pH}$ minimum of solubility for struvites being $~ 9.0$ 11 (Ali et al. 2004). Nevertheless, struvites have also been found to be an efficient fertiliser at neutral and alkaline soil pH (Massey et al. 2009, Uysal and Kuru 2015). This seems counterintuitive, but Talboys et al. (2016) demonstrated that the fertiliser effect was activated by localised excretion of organic acids from plant roots (Jones 1998), highlighting the importance of the plant-

102 soil interface when understanding struvite performance. A further consideration is that as soil $\mathrm{P}$ 103 adsorption capacity increases for example in iron $(\mathrm{Fe})$ and aluminium $(\mathrm{Al})$ rich soils, this could 
104 promote further struvite solubilisation because adsorption of $\mathrm{P}$ onto soil particles lowers the 105 concentration in soil porewater and drives struvite dissolution (Degryse et al. 2017). P

106 solubilisation from struvite is also influenced by the particle size, with smaller grain sizes 107 exhibiting faster reaction rates (Degryse et al. 2017). One of the main advantages of struvite relates 108 therefore to the potential benefit for water quality in terms of reducing $\mathrm{P}$ loss from land to water, 109 when compared to fertilisation with highly soluble fertilisers such as TSP and monoammonium 110 phosphate (MAP) (Talboys et al. 2016, Withers et al. 2014b) (Talboys et al. 2016; Withers et al. $1112014)$.

112 Despite the potential of waste recovered struvites, their reported chemical compositions are not 113 always consistent with pure struvite, which is $12.6 \% \mathrm{P}, 9.9 \%$ magnesium $(\mathrm{Mg})$, and $5.7 \%$ 114 nitrogen (N) (w/w \%) (Ahmed et al. 2018). Furthermore, metal impurities such as Al, Fe, calcium 115 (Ca), and small amounts of heavy metals can also precipitate along with the struvite (Li et al. 116 2019). Such inconsistency in composition was observed by Cabeza et al. (2011) for three struvite 117 products from three separate wastewater treatment plants. In this study struvite from the Gifhorn 118 wastewater treatment plant, Germany (WWTP) contained large amounts of Ca (8.6) and Fe (5.5), 119 and only $5.5 \% \mathrm{Mg}$, whereas the other two products contained 8.5-8.8 \% $\mathrm{Mg}$ resulting in a much 120 lower water solubility (Cabeza et al. 2011). It is unknown if this variation in water solubility was 121 due simply to the presence of metal impurities, or if the metal impurities had immobilized some 122 of the phosphate in inorganic forms other than struvite. It has been demonstrated that struvite synthesized with excess Mg directly decreases the solubilisation of struvite in soil (Degryse et al.

124 2017). Johnston and Richards (2003) investigated the difference in P bioavailability from 125 recovered $\mathrm{P}$ products and found no statistical difference between the biomass yield of perennial 126 ryegrass grown with struvite precipitated from different waste streams, including municipal 127 sewage, corn steep liquor, veal manure, and industrial wastewater (Johnston and Richards 2003). 
128 However, the $\mathrm{P}$ speciation of these struvite products was not determined, which potentially complicates the interpretation of bioavailability.

130 Most studies to date have tended to focus on struvite from a single precipitation facility, therefore 131 cross-sectoral differences between struvite products, stemming from variations in wastewater 132 composition and/or the technological process applied, has largely not been investigated. Even 133 within municipal WWTPs, there can be a significant difference in the size of the facilities, 134 wastewater composition (domestic or industrial), treatment processes and the type of struvite 135 precipitation technology used. As a result there are multiple factors that could potentially lead to 136 inconsistency in the composition, speciation and behaviour of waste recovered P (Lu et al. 2016, 137 Ma et al. 2014).

138 Even though crop response to fertilisation with struvite recovered from wastewater has been investigated (Ahmed et al. 2018), to the best of our knowledge it has not been considered alongside

140 detailed $\mathrm{P}$ speciation analysis of struvite. Struvite has nevertheless been characterized by ${ }^{31} \mathrm{P}$ solid 141 state nuclear magnetic resonance (SSNMR) in kidney stones (Bak et al. 2000), dental materials 142 (Scrimgeour et al. 2007), poultry litter (Hunger et al. 2008), and laboratory synthesized struvite 143 (Ma et al. 2014, Sugiyama et al. 2005). Powder X-ray diffraction (PXRD) of some struvite 144 products has shown the presence of newberyite $\mathrm{Mg}\left(\mathrm{HPO}_{4}\right) \cdot 3 \mathrm{H}_{2} \mathrm{O}$ ( $\mathrm{Lu}$ et al. 2016, Zhang et al. 145 2016). Powder X-ray diffraction, however, only identifies crystalline phases and ignores potential 146 crystal-to-amorphous transformations. The lack of a complete understanding of $\mathrm{P}$ speciation 147 patterns in struvite potentially complicates/impairs our interpretation of $\mathrm{P}$ availability in solum, 148 since without full $\mathrm{P}$ speciation characterisation it is impossible to decipher, authoritatively, the 149 mechanisms of $\mathrm{P}$ release.

$150 \mathrm{P}$ bioavailability and plant uptake is a complex disequilibrium, as the balance between varying $\mathrm{P}$ 151 sorption mechanisms continually changes, with no single technology or methodology mimicking 
exactly the in situ elemental flows. Agronomic and environmental tests for soil bioavailable P are often based on measurements of sodium bicarbonate extractable-P (Olsen-P), but this methodology

154 has been shown to underestimate bioavailable $\mathrm{P}$ in acidic or Fe and Al rich soils (Bell et al., 2005)

155 and operates far outside the norms of $\mathrm{pH}$ (8.5) usually encountered within most soils. An

156 alternative advanced speciation method, namely DGT (Diffusive Gradients in Thin films), which

157 is a passive sampling technology has been compared with Olsen-P (Mason et al., 2010) in field

158 trials and yields an enhanced representation of the plant available P pool and supply flux for labile

159 solutes. Using a DGT passive sampler allows access to the surface binding sites in a controlled

160 and less chemically invasive manner compared to standard extraction methods, similar to the

161 diffusive action of a plant root. However, when these operationally distinct soil tests are used in

162 tandem, identifying differences between the measurements provides further clarity as to how the collective mechanisms of $\mathrm{P}$ release are operating for a given soil, fertiliser or plant interaction.

In this study we investigate the composition, speciation and bioavailability of a range of struvite products, sourced from around the world, made by full-scale struvite precipitation from wastewater by the main technologies in operation to date.

Here we specifically investigate the following:

1. Does elemental composition, $\mathrm{P}$ speciation and solubility vary across the nine struvite products analysed within this study? How do these struvite products compare with the traditional agronomically applied chemical fertilisers?

2. Do differences exist between the struvite products using plant experiments (short term - 4week; long term - 3-month) with L. perenne? Specifically does a) fertiliser performance characteristics vary across the struvite products on low index-P Irish soils; b) what is the 

granular/chemical P fertilisers?

\subsection{Material and Methods}

\subsection{Characteristics of recovered fertilisers}

181 The struvite products used in this study are described in Fig. 1 and the location and technology

182 used for their production are shown in Table 1 (further details are provided in the Supporting

183 Information, SI). Waste recovered struvite samples were selected to represent a range of available struvites from diverse geographic origins. The struvite products are referred to using the following abbreviations: Herning (HER; Denmark), Aaby small (AAS; Denmark), Aaby medium (AAM; Denmark), Aaby large (AAM; Denmark), Helsingør (HEL; Denmark), Xiamen (XIA; China),

187 BerlinerPflanze ${ }^{\mathrm{TM}}$ (BER; Germany), Crystal green $1.5 \mathrm{~mm}$ (CGS; Netherlands), and Crystal green

$1883 \mathrm{~mm}$ (CGL; Netherlands) and mono-ammonium phosphate. All fertiliser samples were ground using a Retsch PM100 ball mill and sieved to $<2 \mathrm{~mm}$ before analysis.

\subsection{Elemental and Speciation analysis}

192 To investigate the metal composition and $\mathrm{P}$ content of the struvite products elemental analysis was performed using ICP-OES (Perkin Elmer Optima 2100 DV). Further details on the instrument setup are provided in the SI. was performed at $11.7 \mathrm{~T}$ on a $500 \mathrm{MHz}$ Jeol ECZ 500R spectrometer with a $3.2 \mathrm{~mm}$ Jeol MAS 
198 NMR probe. Quantitative ${ }^{31} \mathrm{P}$ MAS NMR spectra ( $45^{\circ}$ flip angle) were recorded for all fertiliser

199 samples with $15 \mathrm{kHz}$ magic angle spinning (MAS). The carrier frequency was set at $-9 \mathrm{ppm}$. The

200 recycle delay was optimized for each sample and set to $5 \cdot \mathrm{T}_{1}$ for the $\mathrm{P}$ signal in the sample with

201 longest relaxation, as determined from inversion recovery experiments. Typical recycle delays

202 chosen were 130-800 seconds. Spectra were referenced to $\mathrm{H}_{3} \mathrm{PO}_{4}\left(\delta\left({ }^{31} \mathrm{P}\right)=0 \mathrm{ppm}\right)$, and single-

203 pulse ${ }^{31} \mathrm{P}$ SSNMR spectra were analysed by absolute integration of the resonances in MestReNova

204 after baseline correction using a pure sample of struvite as an external reference (Staal et al. 2019).

205 When spinning side bands were present, they were included in the integration of the signals.

207 2.2.2 Powder X-Ray diffraction. PXRD diffractograms were recorded on a Rigaku Miniflex 600 208 diffractometer using CuKa radiation $(\lambda=1.5418 \AA)$. The data were recorded in the range $2 \theta=3$ $90^{\circ}$ with a step size of 0.02 and a speed $10^{\circ} / \mathrm{min}$. The software PDXL2 from Rigaku was used to match diffractograms with the ICDD library.

\section{$212 \quad$ 2.2.3 Solubility extractions}

213 Tests using $\mathrm{H}_{2} \mathrm{O}$ and $1 \mathrm{M} \mathrm{HCl}$ extractions were carried out to test the solubility differences of the

214 struvite in neutral and acidic solutions. Extractants were made up using water with a resistance of

$21518.2 \mathrm{M} \Omega \cdot \mathrm{cm}\left(\right.$ at $25^{\circ} \mathrm{C}$ ) which were randomly tested using the Molybdenum blue method (Murphy 216 and Riley 1962) to check for a low P concentration ( $<$ LOD). All fertiliser samples were extracted 217 at a ratio of 1:125 (struvite: extractant solution) in their corresponding $\mathrm{H}_{2} \mathrm{O}$ and $1 \mathrm{M} \mathrm{HCl}$ solutions 218 and shaken for 30 minutes at a stable temperature. All samples were centrifuged and filtered, and 219 P content analysed colorimetrically using the Molybdate-blue method (Murphy and Riley 1962).

220 Unplanted soil incubation experiments were used as controls throughout, conducted alongside

221 Experiment A and B (soil treatment and experimental design described below) and measured by 222 DGT analysis. 


\subsection{Plant Experiments}

225 2.3.1 Soil characteristics. The three soils used in this experiment were all collected in Northern 226 Ireland (NI) and ordered via the NI soil classification system (Table 2). The soils were specifically selected to: a) represent the dominant soil types of NI, these being Brown Earth and Gley, b) have a $\mathrm{P}$ index of 0 , and c) exhibit a natural variation in Irish soil $\mathrm{pH}$. The soil used in the 4-week experiment is a Brown Earth (soil 1) collected in Hillsborough, NI (Grid reference: NW355126)

230 from unfertilised field boundaries situated between intensively managed/long-term grassland pasture. The first soil used in the long-term ( 3 month) plant pot experiment was also a Brown Earth (soil 2) collected from the Agri-Food and Biosciences Institute (AFBI), Crossnacreevy experimental farm (Grid reference: NW512241). The second soil used in the long-term pot

234 experiment was a Mineral Gley soil 3) collected at Garvagh, NI (Grid reference: NW022776). Soil

2353 was collected from the field boundary on unfertilised soil from a long-term grass rotation.

2.3.2 Experiment $A$. The fertiliser performance of the struvite products was tested in a short-term (4-week) experiment under highly controlled environmental/growth chamber conditions with perennial ryegrass, to investigate fertiliser performance across the soil types over a range of amendment doses $\left(25,50\right.$ and $\left.100 \mathrm{~kg} \mathrm{P} \mathrm{ha}^{-1}\right)$. Early stage rhizosphere formation was induced in homogeneously packed soil columns $(250 \mathrm{~g}$ soil; $10 \times 6.8 \mathrm{~cm})$ by transplanting a standardised biomass of seedlings ( $\sim 25$ plants, 4 replicates of each treatment) to create a uniform environment to isolate plant-soil-fertiliser interactions.

245 The recommended P fertiliser level for grass establishment on NI soils with P-index 0 (Olsen-P 0$2469 \mathrm{mg} \mathrm{P} \mathrm{kg}^{-1}$ soil) is $120 \mathrm{~kg} \mathrm{P}_{2} \mathrm{O}_{5} \mathrm{ha}^{-1}$, corresponding to $52.3 \mathrm{~kg} \mathrm{P} \mathrm{ha}^{-1}$ (AHDB 2018). Struvite 247 products and chemical fertilisers were ground and added at three levels: the RB209 recommended 
level (50 kg P ha ${ }^{-1}$, corresponding to $\left.73 \mathrm{mg} \mathrm{P} \mathrm{kg} \mathrm{dry} \mathrm{soil}{ }^{-1}\right)$, a low level (25 $\mathrm{kg} \mathrm{P} \mathrm{ha}^{-1}$, corresponding to $\left.36 \mathrm{mg} \mathrm{P} \mathrm{kg} \mathrm{dry} \mathrm{soil}{ }^{-1}\right)$ and a high level (100 $\mathrm{kgP} \mathrm{ha}^{-1}$, corresponding to $\left.146 \mathrm{mg} \mathrm{P} \mathrm{kg} \mathrm{dry} \mathrm{soil}{ }^{-1}\right)$.

250 Ground TSP was added at five levels and served as a control response curve with the following doses: $0,12.5,25,50$, and $100 \mathrm{~kg} \mathrm{P} \mathrm{ha}^{-1}$. The fertilisers were dosed based on their total $\mathrm{P}$ content to ensure that all pots received the same amount of total P. Each soil batch was prepared in the same way: $250 \mathrm{~g}$ of dry soil (sieved to $<2 \mathrm{~mm}$ ) was mixed with a corresponding addition of $\mathrm{P}$ fertiliser, along with a replete supply of $\mathrm{N}$ in the form of $125 \mathrm{mg}$ urea. Nitrogen dosing was undertaken to standardise the experimental conditions and to isolate the impact of $\mathrm{P}$ uptake by the plant. Further information on the experimental set-up is provided in the SI.

2.3.3 Experiment B. A 3-month greenhouse/mesocosm trial ( $5 \mathrm{~kg}$ soil; $30 \mathrm{x} 25 \mathrm{~cm}, \mathrm{n}=3)$ where the different struvites were interrogated using two soils of differing $\mathrm{pH}$ (soil 2: $\mathrm{pH} 6.2$ and soil 3: $\mathrm{pH}$ 5.4), to consider plant growth and plant-soil-fertiliser interactions over a longer time interval.

Soils were treated with a fertiliser dose of $50 \mathrm{~kg} \mathrm{P} \mathrm{ha}^{-1}$ and equivalent N (Urea). Soil 2 was treated with the same fertilisers as the 4-week perennial ryegrass experiment (No P addition, TSP, MAP, XIA, CGL, AAS, HER, BER) whilst soil 3 was only treated with commercially available fertilisers TSP, XIA, CGL, BER and a control treatment with no P addition. Fertilisers were applied to the top layer of soil and mixed by hand to get a homogenous distribution. Soils were left to equilibrate

266 for 4 days and maintained at $65 \%$ WHC. The same Perennial ryegrass germination procedures as 267 for the 4-week trial (Exp. A) were followed with $20 \mathrm{~g}$ of wet biomass transferred into the prepared soil mesocosms (sieved $<2 \mathrm{~mm}$ ). The growth period spanned 3 months with assisted heat and

269 lighting supplied from $8 \mathrm{am}-8 \mathrm{pm}$. Perennial ryegrass shoots and soils were harvested and treated with same protocol from experiment A. 
273 Close-coupled cartesian geometry configured energy dispersive X-Ray Fluorescence (XRF) 274 spectrometry (Rigaku NEX CG) with a fundamental parameters (FP) calibration was used for

275 elemental profiling of soils and ryegrass samples which yielded $\geq 3 \mathrm{~g}$ DM. For quality control, 276 certified reference material (CRM) of Polish mixed herbs (INCT-MPH-2) and soil (ISE 921) were 277 used. The average elemental recovery was $102+/-15 \%$ for plant and $110+/-8 \%$ for soil, a full 278 summary is provided in the SI.

279 Where $<3 \mathrm{~g}$ DM yield was obtained concentrations of $\mathrm{P}, \mathrm{Mg}, \mathrm{Ca}, \mathrm{K}$ and $\mathrm{S}$ were measured after 280 microwave digestion of $0.25 \mathrm{~g}$ of plant material in $5 \mathrm{~mL}$ of concentrated nitric acid (CEM 281 Corporation 2004, Havlin and Soltanpour 1980, Zarcinas et al. 1987). The elements were measured 282 by ICP-OES on an Agilent 5100 at the Agri -Food Bioscience Institute (AFBI), Newforge Lane, 283 Northern Ireland. Total N was measured by dry combustion on a TruMac N (LECO Corporation 284 2012). Total $\mathrm{P}$ in plant shoots were multiplied by DM yield to obtain shoot $\mathrm{P}$ offtake per treatment 285 in all plant samples. by Bell et al. (2005). Soil samples were dried $\left(30^{\circ} \mathrm{C}\right)$ and sieved to $<2 \mathrm{~mm}$. Olsen $\mathrm{P}$ was extracted using 5\% bicarbonate buffered at $\mathrm{pH} 8.5$, in a soil solution ratio 1:20 v/v (Bell et al. 2005, Olsen et al. 1954). The extraction time was 30 minutes at a controlled temperature $\left(22^{\circ} \mathrm{C}\right)$ and samples were then centrifuged to remove the supernatant. The molybdate blue method of Murphy and Riley 292 (1962) was used to determine available P in the sample with modified volumes of $230 \mu$ l of sample and $20 \mu 1$ of molybdenum blue reagent. A 96 well microplate reader with ultra-clear polystyrene microplates was used for analysis, with three analytical replicates per soil sample. 
2.4.3 DGT measurements of plant available P. DGT methods were carried out according to

297 Davison and Zhang (1994) as described by Mason et al. (2008) (see SI, section S11). Binding and 298 diffusive gels were supplied by DGT Research Ltd. Flat sheets (approx. 130 x $130 \mathrm{~mm}$ ) of 299 standard (APA), $0.8 \mathrm{~mm}$ thick diffusive gel, and $0.4 \mathrm{~mm}$ thick FeOH binding gels were cut using 300 the same non-metallic cylindrical cutter (25 mm diameter) for accuracy and consistency. All DGT 301 devices were deployed in $20 \mathrm{~g}$ of dry soil wetted to WHC for $24 \mathrm{hrs}$ in a $35 \mathrm{~mm}$ diameter petri dish. The binding gels were extracted from the DGT devices upon retrieval and eluted in $1 \mathrm{~mL}$ of 1 M HCL solution and measured colorimetrically using the Molybdate-blue method (Murphy and Riley 1962) to determine ${ }^{\mathrm{P}} C_{\text {DGT. }}$

\subsection{Statistical analysis}

307 Data processing and statistical analyses was performed in minitab v. 18 and Prism 8. General 308 Linear Model (GLM) with interaction and Tukey Pairwise comparisons and Principal Component 309 Analysis (PCA) were conducted using Minitab 18 and Regression analysis was conducted using

310 Prism 8. An overview of the performed GLMs can be found in the SI (Table S5).

\subsection{Results}

\subsection{Elemental composition using ICP-OES, ${ }^{31} \mathrm{P}$ SSNMR spectroscopy and PXRD.}

314 The $\mathrm{P}$ concentration of the struvite products varied from 9.0 to $13.6 \% \mathrm{P}$ and the $\mathrm{Mg}$ concentrations 315 were in the range 7.7 to $11.0 \% \mathrm{Mg}$ (Fig. 2 and Table S1). Thus, the $\mathrm{P}$ and $\mathrm{Mg}$ contents of some 316 of the struvite products deviated somewhat from the theoretical $\mathrm{P}$ and $\mathrm{Mg}$ composition of pure 317 struvite, which are $12.6 \%$ and $9.9 \%$, respectively. The BER and HEL samples contain less P than 318 expected, i.e. $9.0 \%$ P for the BER sample and $10.9 \%$ P for the HEL sample. The other struvite 319 products had P contents either close to the theoretical composition or else contained excess P (Fig. 

the struvite products contained excess $\mathrm{Mg}$ (between 1 and 11\%) compared to the theoretical composition, with the exception of samples BER (7.7\%) and HEL (9.5\%).

324 Differences in metal impurities existed between the struvite products (Fig. 2 and Table S3). The 325 BER sample contained a variety of notable metal impurities/enrichments (Al, $\mathrm{Fe}, \mathrm{Ca}, \mathrm{Cu}, \mathrm{Zn}, \mathrm{Pb}$, and $\mathrm{Mn}$ ). The amount of metal impurities varied greatly among the remaining struvite products, e.g. Fe concentration in BER (2993 mg kg-1) and HER (1349 $\mathrm{mg} \mathrm{kg}^{-1}$ ) which were substantially higher than the other struvite products (which typically contained 10-290 $\mathrm{mg} \mathrm{kg}^{-1} \mathrm{Fe}$ ). The BER, and HER samples also contained more Al than the other struvite products, $432 \mathrm{mg} \mathrm{kg}^{-1}$ and $33 \mathrm{mg}$

$330 \mathrm{~kg}^{-1}$, respectively. Ca content also differs among the struvite products, with BER, HER and XIA having the highest $\mathrm{Ca}$ values at $6,823 \mathrm{mg} \mathrm{kg}^{-1}, 1,063 \mathrm{mg} \mathrm{kg}^{-1}$, and 1,096 $\mathrm{mg} \mathrm{kg}^{-1}$, respectively. The BER sample also contained a relatively high concentration of $\mathrm{Zn}$, over five-fold more than any of the other struvites, but this was accompanied by an enrichment in $\mathrm{Pb}$ of $14 \mathrm{mg} \mathrm{kg}^{-1}$ (Table S3). Indeed, the Pb concentrations were considerably more elevated than in the TSP and MAP samples, as well as reporting higher than typical average concentrations for TSP (Guiffre de Lopez Carnelo, et al., 1997).

The TSP sample contains $21.4 \%(\mathrm{w} / \mathrm{w}) \mathrm{P}$ and a series of trace elements (TE) impurities (Tables $\mathrm{S} 2$ and S3). Of note the Cd concentration in the TSP was $23 \mathrm{mg} \mathrm{kg}^{-1}$, whereas all the struvite

340 products tested had levels less than $1 \mathrm{mg} \mathrm{kg}^{-1}$. The MAP sample contains $22.9 \%(\mathrm{w} / \mathrm{w}) \mathrm{P}$, which 341 is $17 \%$ less than the theoretical P content of $26.9 \%$ in monoammonium phosphate. Only small concentrations of TE's $\left(<1 \mathrm{mg} \mathrm{kg}^{-1}\right)$ are present, and MAP contains less $\mathrm{Mg}, \mathrm{Ca}, \mathrm{Al}, \mathrm{Fe}$ and $\mathrm{Mn}$

343 than any of the other fertiliser products (Fig. 2; See SI Table 3). 
344 The ${ }^{31} \mathrm{P}$ SSNMR spectra of the struvite products all contain a resonance at $\delta\left({ }^{31} \mathrm{P}\right)=6.3-6.4 \mathrm{ppm}$, 345 assigned to struvite (Bak et al. 2000). The samples HEL, HER, AAM, and XIA contained a low 346 concentration (1-2.4\%) of an impurity phase at $\delta\left({ }^{31} \mathrm{P}\right)=-7.3 \mathrm{ppm}$ (Table 3), which was assigned 347 to newberyite $\left(\mathrm{Mg}\left(\mathrm{HPO}_{4}\right) \cdot 3 \mathrm{H}_{2} \mathrm{O}\right)$ based on the chemical shift (Hunger et al. 2004).

348 Two large resonances assigned to monocalcium phosphate monohydrate $\left(\mathrm{Ca}\left(\mathrm{H}_{2} \mathrm{PO}_{4}\right)_{2} \cdot \mathrm{H}_{2} \mathrm{O}\right)$ were observed in the ${ }^{31} \mathrm{P}$ SSNMR spectrum of TSP at $\delta\left({ }^{31} \mathrm{P}\right)=0 \mathrm{ppm}$ and $-4.5 \mathrm{ppm}$, along with a smaller resonance at $\delta\left({ }^{31} \mathrm{P}\right)=2.8 \mathrm{ppm}(6 \%)$ assigned to hydroxyapatite $\left(\mathrm{Ca}_{5} \mathrm{OH}\left(\mathrm{PO}_{4}\right)_{3}\right)(\mathrm{Fig}$. S1) (Rothwell et al. 1980). Dittmarite was not identified by the ${ }^{31} \mathrm{P}$ SSNMR, most likely because it is very difficult to distinguish dittmarite from struvite in ${ }^{31} \mathrm{P}$ SSNMR due to very similar chemical shift values, $\delta\left({ }^{31} \mathrm{P}\right)=6.2 \mathrm{ppm}\left(\right.$ Bak et al. 2000) and $\delta\left({ }^{31} \mathrm{P}\right)=6.35 \mathrm{ppm}$ (Kongshaug et al. 2000), respectively.

The ${ }^{31} \mathrm{P}$ SSNMR spectrum of BER contained no resonance in the reported chemical shift range for berlinite, i.e. $\delta\left({ }^{31} \mathrm{P}\right)=-24.5$ to $-25.3 \mathrm{ppm}$ (Bleam et al. 1989, Turner et al. 1986). The spectrum of the sample MAP consisted of one resonance with $\delta\left({ }^{31} \mathrm{P}\right)=1.0 \mathrm{ppm}$, which is consistent with monoammonium phosphate $\left(\mathrm{NH}_{4} \mathrm{H}_{2} \mathrm{PO}_{4}\right)$ (Fig. S1) (Turner et al. 1986).

The PXRD patterns of all struvite products (Fig. 3 and SI Fig. S3) correspond closely to the reference sample pattern for struvite (ICDD no. 01-077-2303) (Ferraris et al. 1986). Only a few impurities were identified by PXRD: the BER sample contained a series of reflections at $2 \theta=26.6$, $36.6,42.5,50.2$, and $60.0^{\circ}$, which match with the aluminum phosphate berlinite $\left(\mathrm{AlPO}_{4}, \mathrm{ICDD}\right.$ no. 01-079-6073) (Labeguerie et al. 2010), and the HER sample shows a strong reflection at $2 \theta=$ $10.0^{\circ}$ and a couple of weaker reflections at $2 \theta=18.8$ and $24.4^{\circ}$ that match dittmarite $\left(\mathrm{MgNH}_{4} \mathrm{PO}_{4} \cdot \mathrm{H}_{2} \mathrm{O}, \mathrm{ICDD}\right.$ no. 00-020-0663) (Frazier et al. 1966).

Furthermore, the HEL sample contains weak reflections at $2 \theta=18.7$ and 28.9 corresponding to newberyite $\left(\mathrm{Mg}\left(\mathrm{HPO}_{4}\right) \cdot 3 \mathrm{H}_{2} \mathrm{O}\right.$, ICDD no. 01-075-1714) (Bartl et al. 1983). These two reflections do not match struvite but could not unambiguously be assigned to newberyite, as reference PXRD 
patterns of newberyite do not cover this $2 \theta$ range. The PXRD of TSP match monocalcium phosphate monohydrate $\left(\mathrm{Ca}\left(\mathrm{H}_{2} \mathrm{PO}_{4}\right)_{2} \cdot \mathrm{H}_{2} \mathrm{O}\right.$, ICDD no.01-075-1521) (Jones and Cruickshank 1961) with a few reflections at $2 \theta=14.7,25.4$, and 25.6 belonging to basanite $\left(\mathrm{CaSO}_{4} \cdot 0.5 \mathrm{H}_{2} \mathrm{O}\right.$, ICDD no. 00-037-0246) (Lager et al. 1984). MAP contains only monoammonium phosphate from the PXRD pattern $\left(\mathrm{NH}_{4} \mathrm{H}_{2} \mathrm{PO}_{4}\right.$, ICDD no.01-072-4581) (Tenzer et al. 1958).

\subsection{Fertiliser product solubilisation}

$\mathrm{H}_{2} \mathrm{O}$ extractable-P is ca. $10 \%$ higher in the chemical fertilisers compared with the struvites, yet conversely the $\mathrm{HCl}$ extractable-P was $15 \%$ lower (Fig. 4). The solubility of individual struvites, tested both by $\mathrm{H}_{2} \mathrm{O}$ and $\mathrm{HCl}$ extractions, differed $(P<0.001, P<0.001$ respectively, Fig. 4). $\mathrm{HCl}$ extractable-P was $17 \%$ higher than $\mathrm{H}_{2} \mathrm{O}$ extractable-P, resolving the struvites into seven groups as opposed to three (Tukey pairwise comparison, Fig.4). Struvite precipitation technology did not influence solubility $\left(\mathrm{H}_{2} \mathrm{O} P=0.724 ; \mathrm{HCl} P=0.765\right.$, see SI, Table S6.1).

Unplanted soil incubation experiments featuring all three soils used showed no difference between struvite fertilisers and TSP behaviour in soil solution at 4-weeks or 3-months. There was no significant difference between the struvites in any of the incubation experiments (GLM analysis, see SI, Table 6.1). There is, however, a difference in ${ }^{\mathrm{P}} C_{\text {DGT }}$ between the three soils $(P<0.05$, Fig. 5). None of the extraction experiments correlate with shoot $\mathrm{P}$ offtake $\left(\mathrm{H}_{2} \mathrm{O} P=0.120 ; 1 \mathrm{M} \mathrm{HCl} P\right.$ $=0.129)$ or planted DGT soil samples $\left(\mathrm{H}_{2} \mathrm{O} P=0.639 ; 1 \mathrm{M} \mathrm{HCl} P=0.461\right)$. Although there is no relationship between the extractions and total $\mathrm{P}$ offtake in perennial ryegrass shoots, there is a strong relationship between incubated soil DGT measurements and DGT measurements in planted systems $\left(\mathrm{R}^{2}=0.7 ; P<0.001\right)$, and between total $\mathrm{P}$ offtake in shoots and DGT measurements in planted systems $\left(\mathrm{R}^{2}=0.80 ; P<0.001\right)$ shown in Fig. 6 . 


\subsubsection{Experiment $A$.}

396 There was no significant difference in shoot yield (GLM analysis $P=0.436$ ), or P-offtake between

397 the different struvite fertilisers and TSP/MAP (GLM analysis $P=0.904$ ) (See SI 6.2-6.4).

398 However, there were differences in the fertiliser dose effect $(P<0.001$, Fig. 7$)$, with higher $\mathrm{P}$ 399 additions increasing growth/yield and P-offtake. The TSP dose response relationship, with five treatment levels showed a strong correlation with yield $\left(\mathrm{R}^{2}=0.88\right)$. Likewise, the individual struvite products showed a strong relationship between dose and $\mathrm{P}$ shoot offtake $\left(\mathrm{R}^{2}=\geq 0.99-1\right.$,

402 Fig. 7). Overall, there is no difference between the struvite products used or any significant 403 deviation in behaviour when compared to chemical fertilisers. There is no overall difference in 404 DGT measured P $\left({ }^{\mathrm{P}} C_{\mathrm{DGT}}\right)$ bioavailability of the struvite products and chemical fertilisers (GLM analysis $P>0.305$ ). Similar to the directly observed plant trends, DGT detected a P dose effect for P offtake (GLM analysis $P<0.001$; Fig. 8). However, this difference in P availability at different

407 dose levels is not detected by Olsen-P (GLM analysis $P=0.232$; Fig. 8).

408

409

\subsubsection{Experiment $B$.}

410 Shoot yield (GLM analysis $P=0.130)$, nor P-offtake (GLM analysis $P=0.288$ ) did not differ

411 between the different struvite fertilisers and TSP/MAP, across both soils (2 and 3, see SI). P412 offtake values for soil 2 averaged $21 \mathrm{mg}$ P and ranged from 19-24 mg P (Fig. 9). Soil 3 has 413 significantly less P offtake with an average of $15 \mathrm{mg} \mathrm{P}$ (29\% less than soil 2$)$. The toxic metals $414 \mathrm{Cr}, \mathrm{Cd}$ and $\mathrm{Pb}$, that were found as impurities in the fertiliser samples (Fig. 2), their concentrations 415 were checked in the harvested plant material. There were no detectable traces $(<\mathrm{LOD})$ of these 416 metals in shoot offtake. 
$418{ }^{\mathrm{P}} \mathrm{C}_{\mathrm{DGT}}$ shows no difference between the fertiliser treatments, but a significant difference between 419 soil 2 and 3 was detected (Fig. 9). In this experiment ${ }^{\mathrm{P}} C_{\text {DGT }}$ measurements correlate with $\mathrm{P}$ offtake 420 (Fig. 7 and Fig. 8), which matches the trends of the 4-week trial (Exp. A), but the overall 421 relationship was stronger $\left(\mathrm{R}^{2}=0.65 ; P<0.001\right.$; Fig. 10). In contrast, Olsen-P showed no 422 relationship with $\mathrm{P}$ offtake $\left(\mathrm{R}^{2}=0.00 ; P=0.984\right.$; Fig. 10$) .{ }^{\mathrm{P}} C_{\mathrm{DGT}}$ and Olsen $\mathrm{P}$ did not correlate $423 \quad\left(\mathrm{R}^{2}=0.04 ; P=0.197\right)$.

\subsection{Comparison of P bioavailability tests.}

426 Olsen-P was found to be a poor predictor of plant $\mathrm{P}$ uptake across all experiments (Fig. 8). DGT, however, successfully estimated the plant requirements (Fig. 6f; Fig. 10). The range of DGT measured P spanned $1.2-179 \mu \mathrm{g} \mathrm{L} \mathrm{L}^{-1}$, which is comparable with other similar soil-P studies (See $\mathrm{S} 6, \mathrm{SI})$. There is a highly significant linear relationship $\left(\mathrm{R}^{2}=0.69 ; P=<0.001\right)$ between $\mathrm{P}$ availability measured by DGT in the unplanted and planted soil experiments (Fig. 6e) indicating a commonality in the supply of $\mathrm{P}$ in the two systems. However, ${ }^{P} \mathrm{C}_{\mathrm{DGT}}$ in the unplanted soils only partially explains plant-P offtake $\left(\mathrm{R}^{2}=0.48 ; P=0.001\right)$. Interestingly, the relationship between

${ }^{P} \mathrm{C}_{\mathrm{DGT}}$ from the planted soils and plant-P offtake was better described using a hyperbolic model 434 (Fig. 6) than a linear term, unlike the unplanted soils. This demonstrates two key points. Firstly, 435 this biphasic characteristics in $\mathrm{P}$ assimilation with an inflexion point at ca. $20 \mu \mathrm{g} \mathrm{L} \mathrm{L}^{-1}$, is in keeping 436 with our understanding of $\mathrm{P}$ transport into plants as explained by high and low-affinity uptake pathways (Meharg and Macnair, 1992), i.e. a plant regulated decrease in $\mathrm{P}$ uptake as $\mathrm{P}$ 438 bioavailability increases. Secondly, the importance of the root-soil-fertiliser interaction.

\subsection{Discussion}

\subsection{Struvite Speciation}


442 Characterisation of the struvite products by SSNMR and PXRD showed that struvite

$443\left(\mathrm{MgNH}_{4} \mathrm{PO}_{4} \cdot 6 \mathrm{H}_{2} \mathrm{O}\right)$ was the dominating phase in all samples tested. Impurities such as newberyite

$444\left(\mathrm{Mg}\left(\mathrm{HPO}_{4}\right) \cdot 3 \mathrm{H}_{2} \mathrm{O}\right)$ only constituted $2.4 \%$ of the $\mathrm{P}$ in the HEL product. Newberyite was the only

445 impurity observed by SSNMR and was present in several of the ${ }^{31} \mathrm{P}$ SSNMR spectra of the struvite

446 products, but was only detected by PXRD for a single sample. Other impurities such as the berlinite

$447\left(\mathrm{AlPO}_{4}\right)$ in the BER sample, and the dittmarite $\left(\mathrm{MgNH}_{4} \mathrm{PO}_{4} \cdot \mathrm{H}_{2} \mathrm{O}\right)$ in the HER sample, were only

448 observed by PXRD. Hence, a combination of the two characterisation methods would appear

449 necessary to gain a comprehensive understanding of $\mathrm{P}$ speciation in the struvite products. Berlinite

450 was observed in PXRD of the BER sample, but the ${ }^{31} \mathrm{P}$ SSNMR spectrum contained no resonance

451 in the reported chemical shift range for berlinite, i.e. $\delta\left({ }^{31} \mathrm{P}\right)=-24.5$ to $-25.3 \mathrm{ppm}$ (Bleam et al.

452 1989, Turner et al. 1986). This discrepancy between the phases observed by SSNMR and PXRD

453 is related to the basis of the two characterisation methods: PXRD identifies crystalline phases,

454 whereas SSNMR differentiates between nuclei of a specific isotope with different local chemical

455 environments in both crystalline and amorphous phase. Hence, if only a very small amount of

456 crystalline berlinite is present, then the phase will be detected by PXRD but not necessarily by ${ }^{31} \mathrm{P}$

457 SSNMR.

458 The traditional granular chemical fertiliser TSP contained the phases expected: MAP was pure 459 mono ammonium phosphate $\left(\mathrm{NH}_{4} \mathrm{H}_{2} \mathrm{PO}_{4}\right)$ from both PXRD and ${ }^{31} \mathrm{P}$ SSNMR, and TSP contained 460 primarily $\mathrm{MCPM}\left(\mathrm{Ca}\left(\mathrm{H}_{2} \mathrm{PO}_{4}\right) 2 \cdot \mathrm{H}_{2} \mathrm{O}\right)$ with $6 \%$ of the $\mathrm{P}$ atoms bound in hydroxyapatite $461\left(\mathrm{Ca}_{10}\left(\mathrm{PO}_{4}\right)_{6}(\mathrm{OH})_{2}\right)$ and some bassanite $\left(\mathrm{CaSO}_{4} \cdot 0.5 \mathrm{H}_{2} \mathrm{O}\right)$ identified by PXRD. As basanite does not 462 contain $\mathrm{P}$, the presence of bassanite cannot be confirmed by ${ }^{31} \mathrm{P}$ SSNMR spectroscopy. Phosphate 463 rock often contains high amounts of apatite (Desmidt et al. 2015) and is used as the basic material 464 for TSP production, which explains the small amounts of unreacted hydroxyapatite in the TSP 465 sample. 
466 Newberyite and dittmarite are closely related to struvite, as they can both form from struvite

467 (Bhuiyan et al. 2008, Snow et al. 2014). Newberyite is a common side product during struvite 468 precipitation (Babíc-Ivancic et al. 2006), and the ratio between struvite and newberyite is affected 469 by, e.g., initial pH (Ma et al. 2014) and N:P ratio in the liquid (Lu et al. 2016).

470 Dittmarite is a rare mineral that has been suggested to form in nature from struvite decomposition 471 in the presence of ammonia, $\mathrm{NH}_{3}$ (Snow et al. 2014). Furthermore, dittmarite can form when 472 struvite is boiled in excess water (Bhuiyan et al. 2008, Sarkar 1991). Newberyite has also been 473 observed in urinary stones, where struvite commonly constitutes the majority of the mineral 474 content (Bak et al. 2000), as well as in poultry litter (Hunger et al. 2008). Both newberyite and 475 dittmarite are known to form in some cases when struvite is precipitated. Zhang and coworkers 476 observed newberyite precipitation along with struvite for synthetic brackish water, whereas 477 struvite precipitation from a digestate filtrate was accompanied by dittmarite precipitation. It was 478 suggested that a higher $\mathrm{NH}_{4}{ }^{+}$concentration was the reason for dittmarite precipitation in the filtrate 479 and not in the synthetic brackish water (Zhang et al. 2016).

480 The presence of $2.4 \%$ of dittmarite in the HER sample is not expected to alter the bioavailability 481 of the struvite product, as dittmarite transforms into struvite when the compound comes in contact 482 with soil moisture (Bridger et al. 1962). This is further supported by a study of the plant availability 483 of dittmarite where dittmarite increased dry matter yields of spring wheat compared to the control, 484 just as struvite and TSP (Massey et al. 2009). However, the plant availability of newberyite has to 485 our knowledge not been investigated. Plus, the overall value of newberyite as a fertiliser is less 486 than struvite, due to the absence of ammonia. Hence precipitation of these phases is undesired. 487 Furthermore, excess Mg in the struvite product has been shown to decrease the P release (Degryse et al. 2017), and this effect was ascribed to local $\mathrm{pH}$ changes in the soil near to the struvite particles, 489 which contained $\operatorname{Mg}(\mathrm{OH})_{2}$ as characterised by PXRD. Impurities like newberyite and dittmarite 
are therefore not expected to decrease the P release from struvite fertilisers dramatically, when only present in these minute amounts.

492 The struvite products used in this study were generally characterised by having low metal impurity concentrations (1-8 $\mathrm{mg} \mathrm{kg}^{-1}$ ) containing significantly less $\mathrm{Cd}, \mathrm{Ni}, \mathrm{Zn}$, and $\mathrm{Cr}$ than the TSP sample.

494 The struvite products were characteristically different in $\mathrm{Fe}, \mathrm{Al}, \mathrm{Ca}, \mathrm{Cu}, \mathrm{Zn}$, and $\mathrm{Mn}$ concentration, with BER, HER and HEL especially exhibiting higher metal levels compared to the other struvite

496 products. This may be ascribed to differences in the technology used for struvite precipitation. The

497 BER sample is precipitated directly in the sludge, which increases the incorporation of organic material and also some metals, whereas the rest of the samples have been precipitated from reject water from the digested sludge. The HEL and HER samples are precipitated by the same technology, Phosphogreen, as the Aaby samples (AAS, AAM, AAL), which are very low in metals. This could indicate that the relatively high metal content of HEL and HER is not caused by the processing technology, but rather factors such as operational set-up, or the composition of the influent wastewater. An interesting observation is that the composition of the struvite products from Aaby differ in metal composition dependant on the size of the struvite particles, which could indicate that operation of the struvite precipitation facility and the WWTP may have an effect.

506 Even though the struvite products demonstrate small differences in metal content, they are still of 507 a higher purity than TSP. Precipitated struvite products contain only trace concentrations of heavy 508 metals (Li et al. 2019), which are considerably lower than that of the traditional commercially available granular inorganic fertilisers (Nziguheba and Smolders 2008) and were also undetectable

510 in the plant XRF analysis.

5124.2 Solubilisation of $P$. The different behaviours of the struvites and chemical fertilisers in $513 \mathrm{H}_{2} \mathrm{O} / \mathrm{HCl}$-extractable $\mathrm{P}$ assays, are predictable, as struvite is scarcely soluble in water at around 1- 
$5145 \%$ (Achat et al. 2014, Cabeza et al. 2011), but almost 100\% soluble in acids (Ahmed et al. 2018).

515 However, why there is differentiation in solubility between the individual struvite products is less

516 obvious. The HEL struvite, which has the greatest dittmarite content at $>2 \%$ along with relatively

517 high concentrations of other elemental impurities, had a higher extractable $\mathrm{P}\left(4 \% \mathrm{H}_{2} \mathrm{O} ; 7 \% \mathrm{HCl}\right)$

518 than the purest struvite products XIA and CGL. However, higher concentrations of metal

519 impurities alone (Fig. 2) did not directly relate to enhanced solubility (see BER and HER samples,

520 Fig. 2), indicating a mixed mode of P-release.

4.3 Struvite in soil. DGT and Olsen-P tests showed that there was no difference in the overall bioavailability of the individual struvite products in Irish soils of the same soil-P index in both 4week and 3-month experiments (Fig. 5; Fig. 8). Even in the soil of the lowest pH (4.8) there was no enhancement in the resolution/differentiation in behaviours between the struvites, unlike the extractable-P trends. Dissolution of $\mathrm{P}$ from struvite in soil is known to be modulated by $\mathrm{pH}$, but $\mathrm{P}$ bioavailability is dependent on $\mathrm{pH}$ as well as other soil characteristics that influence $\mathrm{P}$ fixation processes (Degryse et al. 2016; Penn and Camberato 2019). P retention mechanisms, for example anion and ligand exchange as well as precipitation of $\mathrm{Fe}$ and $\mathrm{Al}$ phosphates, can break the direct relationship between fertiliser solubility and bioavailability (Penn and Camberato 2019). In addition, the total P-bioavailability is not just a measure of fertiliser P supply but is comprised of a contribution from the soil. In our experiments, higher soil $\mathrm{pH}$ resulted in greater overall bioavailability of P from the soils (Fig. 8), which conflicts with struvite solubility trends (Fig. 4), and poses questions regarding the role of soil health and biota.

536 The soils featured in our experiments are typical of the north-east region of the island of Ireland.

537 In addition to exhibiting a low $\mathrm{pH}$, they are also enriched in $\mathrm{Al}$ and $\mathrm{Fe}$, which means $\mathrm{P}$ 538 bioavailability is generally low compared with the total $\mathrm{P}$ concentrations in the soils (Bell et al. 
539 2005). Taking the 3-month experiment and ${ }^{P} \mathrm{C}_{\text {DGT }}$ measurements as an example, the background

540 P supply (i.e. no P addition), measured from the low $\mathrm{pH}$ soil (soil $3-\mathrm{pH} 5.4$ ) averaged $1.2 \mu \mathrm{g} \mathrm{L} \mathrm{L}^{-}$

541 , whereas in soil 2 , with a pH of 6.2 it was nearly an order of magnitude higher at $11 \mu \mathrm{g} \mathrm{L}^{-1}$ (Fig.

542 6). However, the enhancement in additional $P$ availability from the amendment of the soils with

543 the same P fertiliser dose resulted in a 7-fold increase in soil 2 compared to soil 3 (Fig. 5). Further

544 evidence, as to the importance of P-fixation within the soil as a control of bioavailability is

545 presented when ${ }^{P} \mathrm{C}_{\text {DGT }}$ values in the unplanted soils are compared with the extractable $\mathrm{P}$ assays

546 (Fig. 6). The DGT measurement integrates a number of important parameters involved in the

547 bioavailability of $\mathrm{P}$, such as $\mathrm{P}$ release of the soil, $\mathrm{P}$ reabsorption/fixation and fertiliser $\mathrm{P}$ dissolution.

548 Based on understanding of $\mathrm{P}$ solubilisation of the struvites, dissolution would be greater in soil 3

549 because of the lower $\mathrm{pH}$. However, this released $\mathrm{P}$ would be more effectively captured/retained by

550 soil chemical processes, as a consequence of the lower $\mathrm{pH}$. Furthermore, the stronger relationship

551 (ca. $\mathrm{R}^{2}$ 0.70) between DGT and the extractable-P values from soil 2, when compared with soil 3

$552\left(\mathrm{R}^{2}\right.$ 0.34) demonstrate that when $\mathrm{P}$ bioavailability is higher, $\mathrm{P}$ solubilisation patterns play more of 553 a role in defining bioavailability.

554

555

4.3 Struvite in planted systems. A major strength purported for struvite based products is that their fertiliser effect is root activated and hence P release originates in zones within in the soil that have a nutrient requirement. Similar to the unplanted soils, $\mathrm{P}$ availability did not differ in the perennial

558 ryegrass experiments between the struvites and the chemical fertilisers. Although the soil-root

559 interactions within the experiments did not differentiate between the different struvites, there was 560 an overall enhancement of P bioavailability because of the plants. Using again, the examples of 561 soil 2 and 3, the DGT measurement of P shows that P bioavailability increases between 10-20\%

562 (see SI). This is despite considerable P removal by the plants themselves, which would exhaust 563 some of the $\mathrm{P}$ supply within the soil. Interestingly, in the soil with the lowest $\mathrm{pH}$ the gain in $\mathrm{P}$ 
564 bioavailability as a proportion of $\mathrm{P}$ release in the unplanted soil, was double that of the higher $\mathrm{pH}$ soil.

567 The European Commission are revising regulations governing struvite, which will impact on how 568 waste-recovered fertilisers are categorised (Huygens et al., 2018b). Part of this revision process is to CE-mark certify the recycled products based on their manufacturing/processing technologies and waste materials used (Huygens et al., 2018b). The primary advantage this affords, is that the

571 waste status of the recovered product ceases to exist. This makes it easier for recycled materials to

572 be blended, but also confers benefits related to reducing hazard risk and improving product 573 consistency (Huygens et al., 2018b). Using a range of bioavailability/growth tests we have found that not only is struvite as effective as chemical fertiliser, but when amended within Irish soils it gives a uniform response. This provides further evidence that the struvites from different waste sources and precipitation technologies can demonstrate $\mathrm{P}$ conformity, despite differences in

577 physical appearance. The caveat to this though, is that $\mathrm{P}$ solubilisation from struvite has been

578 shown to be influenced by particle size (Degryse et al. 2017), so a classification scheme for struvites that takes into account form, size and morphology would be beneficial. The impact of particle size within Irish soils remains to be determined.

\subsection{Conclusions}

The struvite products generated from different wastewaters and processes do vary in physical appearance and metal impurities, but they do possess uniformity in P speciation (SSNMR, PXRD) and overall fertiliser performance, as demonstrated in our plant experiment trials. Other recovered P fertilisers can be produced from WWTP processes, such as sludge biochar, however, they can

587 provide highly variable yield responses when applied to soil (Glaser and Lehr, 2019). 
Encouragingly, no appreciable agronomic differences were observed between the struvite and chemical fertilisers, which provides further evidence for struvite as a sustainable alternative to mined rock phosphate. Furthermore the struvite products generally contain lower concentrations

591 of metal contaminants, such as $\mathrm{Cd}$. However, $\mathrm{Pb}$ levels should still be monitored in some struvites.

593 Olsen-P is the sector standard for soil $\mathrm{P}$ analysis and is currently widely used for calculating soil P indices. However, plant utilisation of P from struvite amended soils was successfully predicted by ${ }^{P} \mathrm{C}_{\mathrm{DGT}}\left(\mathrm{R}^{2}=0.8\right)$ but not Olsen-P. The DGT measurement integrates parameters such as struvite solubility along with soil re-adsorption processes more effectively than its chemical counterpart (Fig. 6). Struvite offers an opportunity to recover $\mathrm{P}$ and potentially improve agricultural $\mathrm{P}$ use efficiency. However such gains will not be fully realised in Irish soils under current soil testing methodology, nor will it be, if root activated fertilisers are tested and evaluated in systems that do not have the capacity to account for root-soil-fertiliser interactions.

\section{Acknowledgements}

604 This work was supported by the Department for the Economy, Belfast, Northern Ireland (DEL, 605 RH, PNW), and the Innovation Fund Denmark (ReCoverP, grant number 4106-00014, LBS, UGN, $606 \mathrm{KR}$ ). The authors would like to thank the following for providing struvite samples: AarhusVand, 607 Denmark., Berliener Wassebetriebe, Germany, EasyMining, Sweden., Helsingør Forsyning, 608 Denmark., Herning Vand, Ostara, Netherlands., and Qing-Lin Chen and Chao Cai (IUE, CAS, 609 Xiamen), China. Furthermore, the authors would like to thank: Botanical Gardens Belfast 610 (greenhouse space), Paul Cottney (soil 1), AFBI (soil 2, growth chamber space, ICP-OES and TN 611 measurements on plants), Dr. Richard McFaul (soil 3). Christian B. Jørgensen and Nicholai D. 
612 Jensen are thanked for assistance on practical aspects of the NMR. Carina K. Lohmann (SDU) and

613 Alan Wright (AFBI, Newforge) is thanked for performing the ICP-OES analysis.

614

\section{References}

616 Achat DL, Sperandio M, Daumer ML, Santellani AC, Prud'Homme L, Akhtar M, Morel C

617 (2014) Plant-availability of phosphorus recycled from pig manures and dairy effluents as

618

619

620

621

622

623

624

625

626

627

628

629

630

631

632

633

634

635

636

637

638

639

640

641

642

643

644

645

646

647 assessed by isotopic labeling techniques Geoderma 232:24-33 doi:https://doi.org/10.1016/j.geoderma.2014.04.028

AHDB (2018) Nitrates Action Programme 2015-2018 and Phosphorus Regulations Guidance Booklet

Ahmed N, Shim S, Won S, Ra C (2018) Struvite recovered from various types of wastewaters: Characteristics, soil leaching behaviour, and plant growth Land Degradation \& Development 0 doi:https://doi.org/doi:10.1002/ldr.3010

Ali I, Schneider Phil A (2005) Crystallization of struvite from metastable region with different types of seed crystal vol 30. doi:https://doi.org/10.1515/JNETDY.2005.007

Babíc-Ivancic V, Kontrec J, Brecevic L, Kralj D (2006) Kinetics of struvite to newberyite transformation in the precipitation system $\mathrm{MgCl}_{2}-\mathrm{NH}_{4} \mathrm{H}_{2} \mathrm{PO}_{4}-\mathrm{NaOH}-\mathrm{H}_{2} \mathrm{O}$ Water Research 40:3447-3455 doi:https://doi.org/10.1016/j.watres.2006.07.026

Bak M, Thomsen JK, Jakobsen HJ, Petersen SE, Petersen TE, Nielsen NC (2000) Solid-state ${ }^{13} \mathrm{C}$ and ${ }^{31} \mathrm{P}$ NMR analysis of urinary stones Journal of Urology 164:856-863 doi:https://doi.org/10.1016/s0022-5347(05)67327-2

Bartl H, Catti M, Joswig W, Ferraris G (1983) Investigation of the crystal-structure of newberyite, $\mathrm{MgHPO}_{4} .3 \mathrm{H}_{2} \mathrm{O}$, by single-crystal neutron-diffraction Tschermaks Mineralogische Und Petrographische Mitteilungen 32:187-194 doi:https://doi.org/10.1007/bf01081109

Bell AAW, Bailey JS, Smith RV (2005) An evaluation of the Olsen test as a measure of plantavailable phosphorus in grassland soils derived from basalt parent material Soil Use and Management 21:322-329 doi:https://doi.org/10.1079/sum2005329

Bhuiyan MIH, Mavinic DS, Koch FA (2008) Thermal decomposition of struvite and its phase transition Chemosphere 70:1347-1356 doi:https://doi.org/10.1016/j.chemosphere.2007.09.056

Bleam WF, Pfeffer PE, Frye JS (1989) ${ }^{31}$ P solid-state nuclear magnetic-resonance spectroscopy of aluminum phosphate minerals Physics and Chemistry of Minerals 16:455-464 doi:https://doi.org/10.1007/BF00197015 
661

662

663

664

665

666

667

668

669

670

671

672

673

674

675

676

677

678

679

680

681

682

683

684

685

686

687

688

689

690

691

692

693

694

695

696

697

698

699

700

701

702

703

704

705

Bridger GL, Starostka RW, Salutsky ML (1962) Micronutrient sources - metal ammonium phosphates as fertilizers J Agric Food Chem 10:181-\& doi:https://doi.org/10.1021/jf60121a006

Cabeza R, Steingrobe B, Romer W, Claassen N (2011) Effectiveness of recycled P products as P fertilizers, as evaluated in pot experiments Nutrient Cycling in Agroecosystems 91:173184 doi:https://doi.org/10.1007/s10705-011-9454-0

CEM Corporation (2004) Sample Preparation Note 3051-7 MARS Operating Manual. CEM Corporation,

Cordell D, White S (2011) Peak phosphorus: Clarifying the key issues of a vigorous debate about long-term phosphorus security Sustainability 3:2027-2049 doi:https://doi.org/10.3390/su3102027

Chakoumakos SB, Boatner, B, Ramey, J (1992). Structural evolution of the amorphous solids produced by heating crystalline MgHPO4 - 3H2O Journal of Materials Research, 7-10: 2646-2649. doi: https://10.1557/JMR.1992.2646

Cruickshank JG (1997) The Soils: Their Nature and Variability In: Soil and environment: Northern Ireland. DANI Belfast,

Davison W, Zhang H (1994) In-situ speciation if trace components in natural waters using thinfilm gels Nature 367:546-548 doi:https://doi.org/10.1038/367546a0

Ding S, Wang Y, Zhang L, Xu L, Gong M, Zhang C (2016) New holder configurations for use in the diffusive gradients in thin films (DGT) technique. RSC Adv.

doi:https://10.1039/C6RA19677B

Degryse F, Baird R, da Silva RC, McLaughlin MJ (2017) Dissolution rate and agronomic effectiveness of struvite fertilizers - effect of soil $\mathrm{pH}$, granulation and base excess Plant and Soil 410:139-152 doi:https://doi.org/10.1007/s11104-016-2990-2

Desmidt E et al. (2015) Global phosphorus scarcity and full-scale P-recovery techniques: A review Critical Reviews in Environmental Science and Technology 45:336-384 doi:https://doi.org/10.1080/10643389.2013.866531

Duboc O, Santner J, Golestani Fard A, Zehetner F, Tacconi J, Wenzel WW (2017) Predicting phosphorus availability from chemically diverse conventional and recycling fertilizers The Science of the total environment 599-600:1160-1170 doi:https://doi.org/10.1016/j.scitotenv.2017.05.054

Ferraris G, Fuess H, Joswig W (1986) Neutron-diffraction study of $\mathrm{MgNH}_{4} \mathrm{PO}_{4} \cdot 6 \mathrm{H}_{2} \mathrm{O}$ (struvite) and survey of water-molecules donating short hydrogen-bonds Acta Crystallographica Section B-Structural Science Crystal Engineering and Materials 42:253-258 doi:https://doi.org/10.1107/s0108768186098269

Frazier AW, Smith JP, Lehr JR (1966) Precipitated impurities in fertilizers prepared from wetprocess phosphoric acid J Agric Food Chem 14:522-\& doi:https://doi.org/10.1021/jf60147a026 
Ganrot Z, Dave G, Nilsson E (2007) Recovery of N and P from human urine by freezing, struvite precipitation and adsorption to zeolite and active carbon Bioresource Technology 98:3112-3121 doi:https://doi.org/10.1016/j.biortech.2006.10.038

Gell K, Ruijter FJ, Kuntke P, de Graaff M, Smit AL (2011) Safety and effectiveness of struvite from black water and urine as a phosphorus fertilizer Journal of Agricultural Science 3:67-80 doi:https://doi.org/10.5539/jas.v3n3p67

Giuffréde López Carnelo L, Ratto de Miguez S, Marbán L (1997) Heavy metals input with phosphate fertilizers used in Argentina Science of the Total Environment 204: 245-250 doi: https://doi.org/10.1016/S0048-9697(97)00187-3

Havlin JL, Soltanpour PN (1980) A nitric-acid plant-tissue digest method for use with inductively coupled plasma spectrometry Communications in Soil Science and Plant Analysis 11:969-980 doi:https://doi.org/10.1080/00103628009367096

Hilt K, Harrison J, Bowers K, Stevens R, Barry A, Harrison K (2016) Agronomic response of crops fertilized with struvite derived from dairy manure Water, Air, \& Soil Pollution 227:388 doi:https://doi.org/10.1007/s11270-016-3093-7

Hunger S, Cho H, Sims JT, Sparks DL (2004) Direct speciation of phosphorus in alum-amended poultry litter: Solid-state ${ }^{31} \mathrm{P}$ NMR investigation Environmental Science \& Technology 38:674-681 doi:https://doi.org/10.1021/es034755s

Hunger S, Sims JT, Sparks DL (2008) Evidence for struvite in poultry litter: Effect of storage and drying Journal of Environmental Quality 37:1617-1625 doi:https://doi.org/10.2134/jeq2007.0331

Huygens D, Saveyn HGM (2018) Agronomic efficiency of selected phosphorus fertilisers derived from secondary raw materials for European agriculture. A meta-analysis Agronomy for Sustainable Development 38:52 doi:https://doi.org/10.1007/s13593-018$\underline{0527-1}$

Huygens D, Saveyn HGM, Tonini PE, Sancho LD (2018) DRAFT STRUBIAS recovery rules and market study for precipitated phosphate salts \& derivates, thermal oxidation materials $\&$ derivates and pyrolysis \& gasification materials in view of their possible inclusion as Component Material Categories in the Revised Fertiliser Regulation. Circular Economy and Industrial Leadership Unit, Directorate B - Growth and Innovation, Joint Research Centre - European Commission.

Johnston AE, Richards IR (2003) Effectiveness of different precipitated phosphates as phosphorus sources for plants Soil Use and Management 19:45-49 doi:https://doi.org/10.1079/sum2002162

Jones DL (1998) Organic acids in the rhizosphere - a critical review Plant and Soil 205:25-44 doi:https://doi.org/10.1023/a:1004356007312

Jones DW, Cruickshank DW, J. (1961) The crystal structures of two calcium orthophosphates: $\mathrm{CaHPO}_{4}$ and $\mathrm{Ca}\left(\mathrm{H}_{2} \mathrm{PO}_{4}\right)_{2} \cdot \mathrm{H}_{2} \mathrm{O}$ vol 116 . doi:https://doi.org/10.1524/zkri.1961.116.16.101 
Kongshaug KO, Fjellvag H, Lillerud KP (2000) Synthesis and ab-initio structure determination of organically templated magnesium phosphates from powder diffraction data J Mater Chem 10:1915-1920 doi:https://doi.org/10.1039/B001715I

Labeguerie P, Harb M, Baraille I, Rerat M (2010) Structural, electronic, elastic, and piezoelectric properties of alpha-quartz and $\mathrm{MXO}_{4}(\mathrm{M}=\mathrm{Al}, \mathrm{Ga}, \mathrm{Fe} ; \mathrm{X}=\mathrm{P}, \mathrm{As})$ isomorph compounds: A DFT study Physical Review B 81 doi:https://doi.org/10.1103/PhysRevB.81.045107

Lager GA, Armbruster T, Rotella FJ, Jorgensen JD, Hinks DG (1984) A crystallographic study of the low-temperature dehydration products of gypsum, $\mathrm{CaSO}_{4} .2 \mathrm{H}_{2} \mathrm{O}$ - hemihydrate $\mathrm{CaSO}_{4} \cdot 0.50 \mathrm{H}_{2} \mathrm{O}$, and gamma-CaSO 4 American Mineralogist 69:910-919

LECO Corporation (2012) Application note: Nitrogen in soil and plant tissue using the TruMac (-394). Michigan, USA

Li B, Boiarkina I, Yu W, Huang HM, Munir T, Wang GQ, Young BR (2019) Phosphorous recovery through struvite crystallization: Challenges for future design Sci Total Environ 648:1244-1256 doi:https://doi.org/10.1016/j.scitotenv.2018.07.166

Lu X, Shih K, Li X-y, Liu G, Zeng EY, Wang F (2016) Accuracy and application of quantitative X-ray diffraction on the precipitation of struvite product Water Research 90:9-14 doi:https://doi.org/10.1016/j.watres.2015.12.014

Ma N, Rouff AA, Phillips BL (2014) A ${ }^{31}$ P NMR and TG/DSC-FTIR investigation of the influence of initial $\mathrm{pH}$ on phosphorus recovery as struvite Acs Sustainable Chemistry \& Engineering 2:816-822 doi:https://doi.org/10.1021/sc4004746

Mason S, Harnon R, Zhang H, Anderson J (2008) Investigating chemical constraints to the measurement of phosphorus in soils using diffusive gradients in thin films (DGT) and resin methods Talanta 74:779-787 doi:https://doi.org/10.1016/j.talanta.2007.07.005

Mason S, McNeill A, McLaughlin MJ, Zhang H (2010) Prediction of wheat response to an application of phosphorus under field conditions using diffusive gradients in thin-films (DGT) and extraction methods Plant and Soil 337:243-258 doi:https://doi.org/10.1007/s11104-010-0521-0

Massey MS, Davis JG, Ippolito JA, Sheffield RE (2009) Effectiveness of recovered magnesium phosphates as fertilizers in neutral and slightly alkaline soils Agronomy Journal 101:323329 doi:https://doi.org/10.2134/agronj2008.0144

Mayer BK et al. (2016) Total value of phosphorus recovery Environmental Science \& Technology 50:6606-6620 doi:https://doi.org/10.1021/acs.est.6b01239

Meharg, AA, Macnair, MR (1992) Suppression of the High Affinity Phosphate Uptake System: A Mechanism of Arsenate Tolerance in Holcus lanatus L Journal of Experimental Botany 43- 4: 519-524 doi: https://doi.org/10.1093/jxb/43.4.519 
Muhmood A, Lu J, Dong R, Wu S (2019) Formation of struvite from agricultural wastewaters and its reuse on farmlands: Status and hindrances to closing the nutrient loop Journal of Environmental Management 230:1-13 doi:https://doi.org/10.1016/j.jenvman.2018.09.030

Murphy J, Riley JP (1962) A modified single solution method for determination of phosphate in natural waters Anal Chim Acta 26:31-\& doi:https://doi.org/10.1016/S0003$\underline{2670(00) 88444-5}$

Nziguheba G, Smolders E (2008) Inputs of trace elements in agricultural soils via phosphate fertilizers in European countries Sci Total Environ 390:53-57 doi:https://doi.org/10.1016/j.scitotenv.2007.09.031

Olsen SR, Cole CV, Watanabe FS, Dean LA (1954) Estimation of available phosphorus in soils by extraction with sodium bicarbonate. Circular 939, United States Department of Agriculture Washington DC

Penn JC, Camberato JJ (2019) A Critical Review on Soil Chemical Processes that Control How Soil pH Affects Phosphorus Availability to Plants Agriculture 9-6: 120-136 https://doi:10.3390/agriculture9060120

Plaza C, Sanz R, Clemente C, Fernandez JM, Gonzalez R, Polo A, Colmenarejo MF (2007) Greenhouse evaluation of struvite and sludges from municipal wastewater treatment works as phosphorus sources for plants J Agric Food Chem 55:8206-8212 doi:https://doi.org/10.1021/jf071563y

Rasul GAM, Esmail AO, Mekha RJ (2011) The role of magnesium in increasing of phosphorus fertilizer efficiency and wheat yield Mesopotamia Journal of Agriculture 39:33-39

Recena R, Torrent J, del Campillo MC, Delgado A (2015) Accuracy of Olsen P to assess plant P uptake in relation to soil properties and P forms Agronomy for Sustainable Development 35:1571-1579 doi:https://doi.org/10.1007/s13593-015-0332-z

Rech I, Withers PJA, Jones DL, Pavinato PS (2019) Solubility, Diffusion and Crop Uptake of Phosphorus in Three Different Struvites Sustainability 11:134 doi:https://doi.org/10.3390/su11010134

Rothwell WP, Waugh JS, Yesinowski JP (1980) High-resolution variable-temperature ${ }^{31}$ P NMR of solid calcium phosphates Journal of the American Chemical Society 102:2637-2643 doi:https://doi.org/10.1021/ja00528a020

Sarkar AK (1991) Hydration dehydration characteristics of struvite and dittmarite pertaining to magnesium ammonium phosphate cement systems Journal of Materials Science 26:25142518 doi:https://doi.org/10.1007/bf01130204

Scrimgeour SN, Chudek JA, Lloyd CH (2007) The determination of phosphorus containing compounds in dental casting investment products by ${ }^{31} \mathrm{P}$ solid-state MAS-NMR spectroscopy Dental Materials 23:415-424 doi:https://doi.org/10.1016/j.dental.2006.02.010 
Six, L., Smolders, E., \& Merckx, R. (2013). The performance of DGT versus conventional soil phosphorus tests in tropical soils - maize and rice responses to $\mathrm{P}$ application Plant and Soil,366(1/2), 49-66 doi: $\underline{10.1007 / \mathrm{s} 11104-012-1192-9}$

Snow MR, Pring A, Allen N (2014) Minerals of the Wooltana Cave, Flinders Ranges, South Australia Transactions of the Royal Society of South Australia 138:214-230 doi:https://doi.org/10.1080/03721426.2014.11649009

Staal LB, Petersen AB, Jørgensen CA, Nielsen UG, Nielsen PH, Reitzel K (2019) Extraction and quantification of polyphosphates in activated sludge from waste water treatment plants by 31P NMR spectroscopy Water Research 157:346-355 doi:https://doi.org/10.1016/j.watres.2019.03.065

Sugiyama S, Fujisawa M, Yokoyama M, Sotowa KI, Tomida T, Shigemoto N (2005) Employment of ${ }^{31} \mathrm{P}$ MAS NMR for the identification of amorphous precipitation products obtained from the MAP process Bull Chem Soc Jpn 78:2245-2250 doi:https://doi.org/10.1246/bcsj.78.2245

Szymańska M, Szara E, Wąs A, Sosulski T, van Pruissen GWP, Cornelissen RL (2019) Struvite-An Innovative Fertilizer from Anaerobic Digestate Produced in a Bio-Refinery Energies 12:296 doi:https://doi.org/10.3390/en12020296

Talboys PJ, Heppell J, Roose T, Healey JR, Jones DL, Withers PJA (2016) Struvite: a slowrelease fertiliser for sustainable phosphorus management? Plant and Soil 401:109-123 doi:https://doi.org/10.1007/s11104-015-2747-3

Tenzer L, Frazer BC, Pepinsky R (1958) A neutron structure analysis of tetragonal $\mathrm{NH}_{4} \mathrm{H}_{2} \mathrm{PO}_{4}$ Acta Crystallographica 11:505-509 doi:https://doi.org/10.1107/s0365110x58001389

Turner GL, Smith KA, Kirkpatrick RJ, Oldfieldt E (1986) Structure and cation effects on phosphorus-31 NMR chemical shifts and chemical-shift anisotropies of orthophosphates Journal of Magnetic Resonance (1969) 70:408-415 doi:https://doi.org/10.1016/0022$\underline{2364(86) 90129-0}$

Uysal A, Kuru B (2015) The fertilizer effect of struvite recovered from dairy industry wastewater on the growth and nutrition of maize plant Fresenius Environ Bull 24:31553162

Withers PJA, Sylvester-Bradley R, Jones DL, Healey JR, Talboys PJ (2014) Feed the crop not the soil: Rethinking phosphorus management in the food chain Environmental Science \& Technology 48:6523-6530 doi:https://doi.org/10.1021/es501670j

Zarcinas BA, Cartwright B, Spouncer LR (1987) Nitric-acid digestion and multielement analysis of plant-material by inductively coupled plasma spectrometry Communications in Soil Science and Plant Analysis 18:131-146 doi:https://doi.org/10.1080/00103628709367806

Zhang XD, Hu JM, Spanjers H, van Lier JB (2016) Struvite crystallization under a marine/brackish aquaculture condition Bioresource Technology 218:1151-1156 doi:https://doi.org/10.1016/j.biortech.2016.07.088 
Table 1: Overview of the fertiliser products characterised in this study. All samples were ground and sieved to give a particle size of $\leq 2 \mathrm{~mm}$.

\begin{tabular}{|c|c|c|c|}
\hline Material & Abbreviation & Source & Struvite technology \\
\hline Triple super phosphate & TSP & $\begin{array}{l}\text { Triple super phosphate } \\
\text { from Goulding } \\
\text { Fertiliser NI. }\end{array}$ & 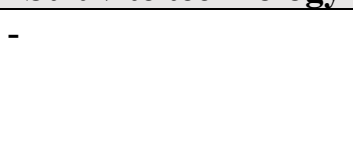 \\
\hline cleanMAP ${ }^{\circledR}$ & MAP & $\begin{array}{l}\text { Mono ammonium } \\
\text { phosphate recovered } \\
\text { from wastewater } \\
\text { sludge ash by the } \\
\text { company Easymining }\end{array}$ & \\
\hline Chinese struvite & XIA & $\begin{array}{l}\text { Struvite from } \\
\text { anaerobically digested } \\
\text { swine waste water in } \\
\text { Xiamen, China }\end{array}$ & $\begin{array}{l}\text { Struvite precipitation } \\
\text { by stirred reactor } \\
\text { (Chen et al. 2017, } \\
\text { Chen et al. 2018) }\end{array}$ \\
\hline $\begin{array}{l}\text { Crystal Green }{ }^{\circledR} \text { small } \\
\text { and large }\end{array}$ & $\begin{array}{l}\text { CGS } \\
\text { CGL }\end{array}$ & $\begin{array}{l}\text { Commercially } \\
\text { available struvite from } \\
\text { Ostara in small }(1.5 \\
\mathrm{mm}) \text { and large }(3 \mathrm{~mm}) \\
\text { pellets. }\end{array}$ & PEARL \\
\hline $\begin{array}{l}\text { Aaby small, medium } \\
\text { and large }\end{array}$ & $\begin{array}{l}\text { AAS } \\
\text { AAM } \\
\text { AAL }\end{array}$ & $\begin{array}{l}\text { Struvite from full- } \\
\text { scale struvite } \\
\text { production at Aaby } \\
\text { WWTP, Aarhus Vand, } \\
\text { Denmark in small }(1 \\
\text { mm }) \text {, medium }(2 \mathrm{~mm}) \\
\text { and large }(3 \mathrm{~mm}) \\
\text { pellets. }\end{array}$ & Phosphogreen \\
\hline Herning & HER & $\begin{array}{l}\text { Struvite from full- } \\
\text { scale struvite } \\
\text { production at Herning } \\
\text { WWTP, Herning } \\
\text { Vand, Denmark }\end{array}$ & Phosphogreen \\
\hline Helsingør & HEL & $\begin{array}{l}\text { Struvite from full- } \\
\text { scale struvite } \\
\text { production at } \\
\text { Helsingør WWTP, }\end{array}$ & Phosphogreen \\
\hline Berliner Pflanze ${ }^{\circledR}$ & BER & $\begin{array}{l}\text { Commercially } \\
\text { available struvite from } \\
\text { a full-scale struvite } \\
\text { production from } \\
\text { Berliner } \\
\text { Wasserbetriebe. }\end{array}$ & Airprex \\
\hline
\end{tabular}


Table 2: Overview of soil characteristics

\begin{tabular}{cccc}
\hline & Soil 1 & Soil 2 & Soil 3 \\
\hline American soil classification & Gray-brown & Gray-brown & Humic-gley soil \\
system 1938 & podzolic soils & podzolic soils & \\
Texture & Sandy clay loam & Sandy clay loam & Organic sandy texture \\
pH & 4.8 & 6.2 & 5.4 \\
Total P $(\mathrm{mg} / \mathrm{g})$ & 0.7 & 2.3 & 1.7 \\
Total Al $(\mathrm{mg} / \mathrm{g})$ & 74 & 81 & 70 \\
Total Fe $(\mathrm{mg} / \mathrm{g})$ & 32 & 33 & 31 \\
Total $\mathrm{Mg}(\mathrm{mg} / \mathrm{g})$ & 11 & 14 & 13 \\
Total Ca $(\mathrm{mg} / \mathrm{g})$ & 2 & 3.5 & 2 \\
\hline
\end{tabular}

Table 3: Overview of phase composition of fertiliser samples from ${ }^{31} \mathrm{P}$ MAS SSNMR and PXRD. Chemical shift $\left(\delta\left({ }^{31} \mathrm{P}\right)\right.$ and integral (I) of SSNMR resonances are given. Phases are indicated by their names: Struvite $\left(\mathrm{MgNH}_{4} \mathrm{PO}_{4} \cdot 6 \mathrm{H}_{2} \mathrm{O}\right)$, Newberyite $\left(\mathrm{Mg}\left(\mathrm{HPO}_{4}\right) \cdot 3 \mathrm{H}_{2} \mathrm{O}\right)$, Berlinite $\left(\mathrm{AlPO}_{4}\right)$, Dittmarite $\left(\mathrm{MgNH}_{4} \mathrm{PO}_{4} \cdot \mathrm{H}_{2} \mathrm{O}\right)$, Bassanite $\left(\mathrm{CaSO}_{4} \cdot 0.5 \mathrm{H}_{2} \mathrm{O}\right)$, Monocalcium phosphate monohydrate (MCPM, $\mathrm{Ca}\left(\mathrm{H}_{2} \mathrm{PO}_{4}\right)_{2} \cdot \mathrm{H}_{2} \mathrm{O}$, Hydroxyapatite $\left(\mathrm{Ca}_{10}\left(\mathrm{PO}_{4}\right)_{6}(\mathrm{OH})_{2}\right)$, and monoammonium phosphate (MAP, $\left.\mathrm{NH}_{4} \mathrm{H}_{2} \mathrm{PO}_{4}\right)$. Estimated uncertainties are given in brackets. * not detected in PXRD. 


\begin{tabular}{lllll}
\hline Sample & Phase(s) & $\begin{array}{l}\boldsymbol{\delta}\left({ }^{\mathbf{3}} \mathbf{P}\right) \\
(\mathbf{p p m})\end{array}$ & $\begin{array}{l}\mathbf{I} \\
\mathbf{( \% )}\end{array}$ & Comments \\
\hline TSP & MCPM & -4.5 & $48(1)$ & Bassanite (PXRD) \\
& & 0.0 & $46(1)$ & \\
MAP & Hydroxyapatite* & 2.8 & $6(1)$ & \\
XIA & MAP & 1.0 & 100 & \\
& Struvite & 6.4 & $100(1)$ & \\
CGS & Newberyite* & -7.3 & $0(1)$ & \\
CGL & Struvite & 6.3 & 100 & \\
AAS & Struvite & 6.3 & 100 & \\
AAM & Struvite & 6.3 & 100 & \\
& Struvite & 6.4 & $100(1)$ & \\
AAL & Newberyite* & -7.3 & $0(1)$ & \\
HER & Struvite & 6.3 & 100 & \\
& Struvite & 6.4 & $99(1)$ & Dittmarite (PXRD) \\
HEL & Newberyite* & -7.3 & $0.6(10)$ & \\
& Struvite & 6.4 & $97.6(10)$ & \\
BER & Newberyite* & -7.3 & $2.4(10)$ & Berlinite (PXRD) \\
\hline
\end{tabular}




\section{Figures}

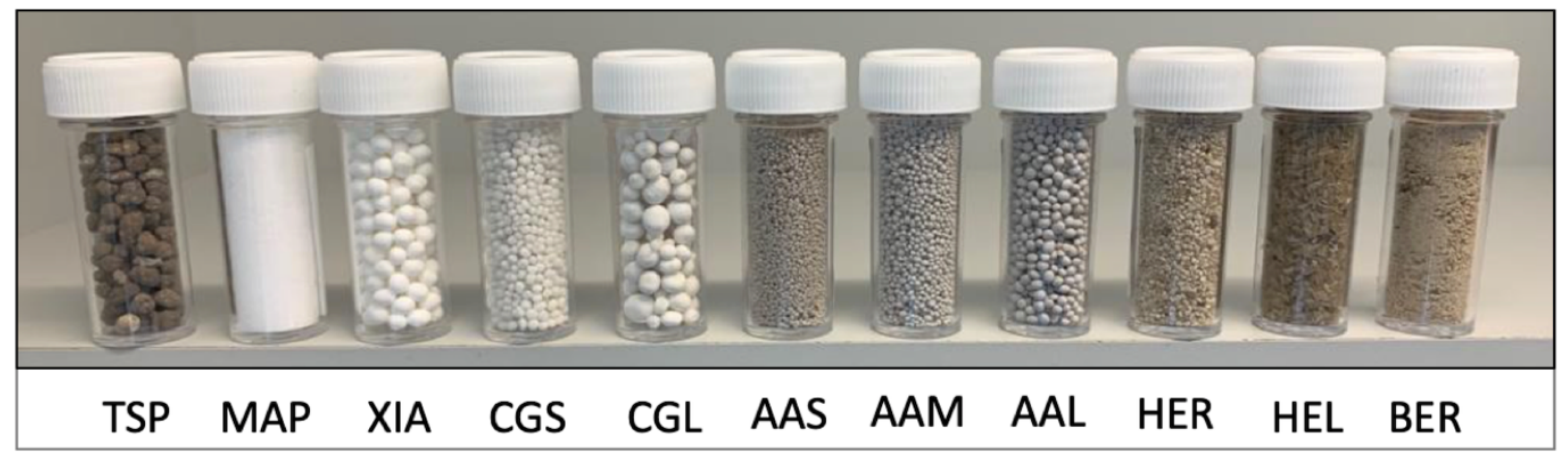

Figure 1: Struvite products investigated in this study. 
a. Chemical Fertilisers \& Airpex (BER)

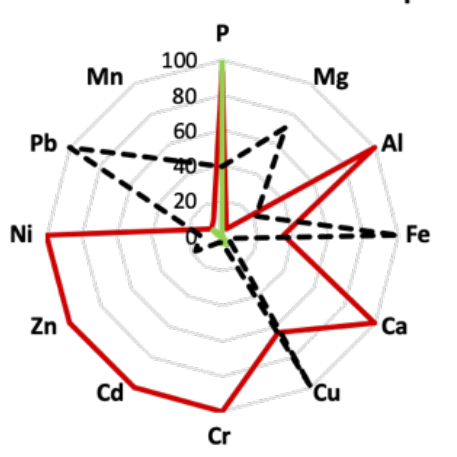

b. Pearl and Swine Manure

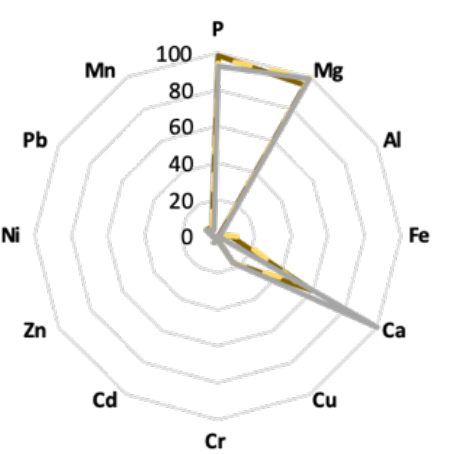

C. Phosphogreen

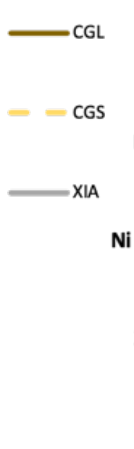

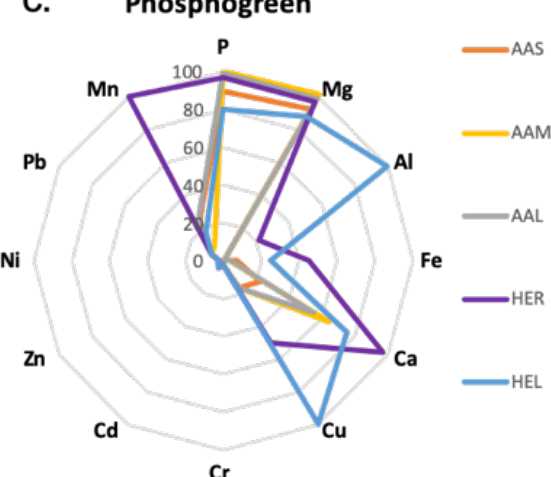

Figure 2. Elemental Characteristics of P Fertilisers. a) Radar chart of the TSP control and monoammonium phosphate (MAP) fertilisers and BER struvite. b-c) Radar charts of the struvite fertilisers by different production technologies. Analysis was undertaken by ICP-OES. Radar charts show percent. $100 \%$ is calculated as the highest reading for any respective element in a.), $100 \%$ for each element is respective to $\%$ of P) $22.9, \mathrm{Mg}$ ) $10.8, \mathrm{Al}) 0.20, \mathrm{Fe}$ ) $0.30, \mathrm{Ca}) 18.71, \mathrm{Cu}$ ) $0.01, \mathrm{Cr}) 0.013, \mathrm{Cd}) 0.002, \mathrm{Zn}) 0.05$, Ni) $0.003 \mathrm{~Pb}$ ) $0.001, \mathrm{Mn}) 0.02$. b-c) $100 \%$ is calculated as the highest reading for any respective element in the WRS from Pearl, swine manure and Phosphogreen. $100 \%$ for each element in $\mathrm{b}$-c) is respective to $\%$ of $\mathrm{P}$ ) $13.6, \mathrm{Mg}$ ) $10.8, \mathrm{Al}) 0.015$, $\mathrm{Fe}) 0.3, \mathrm{Ca}) 0.11, \mathrm{Cu}) 0.0006, \mathrm{Mn}) 0.002$. 

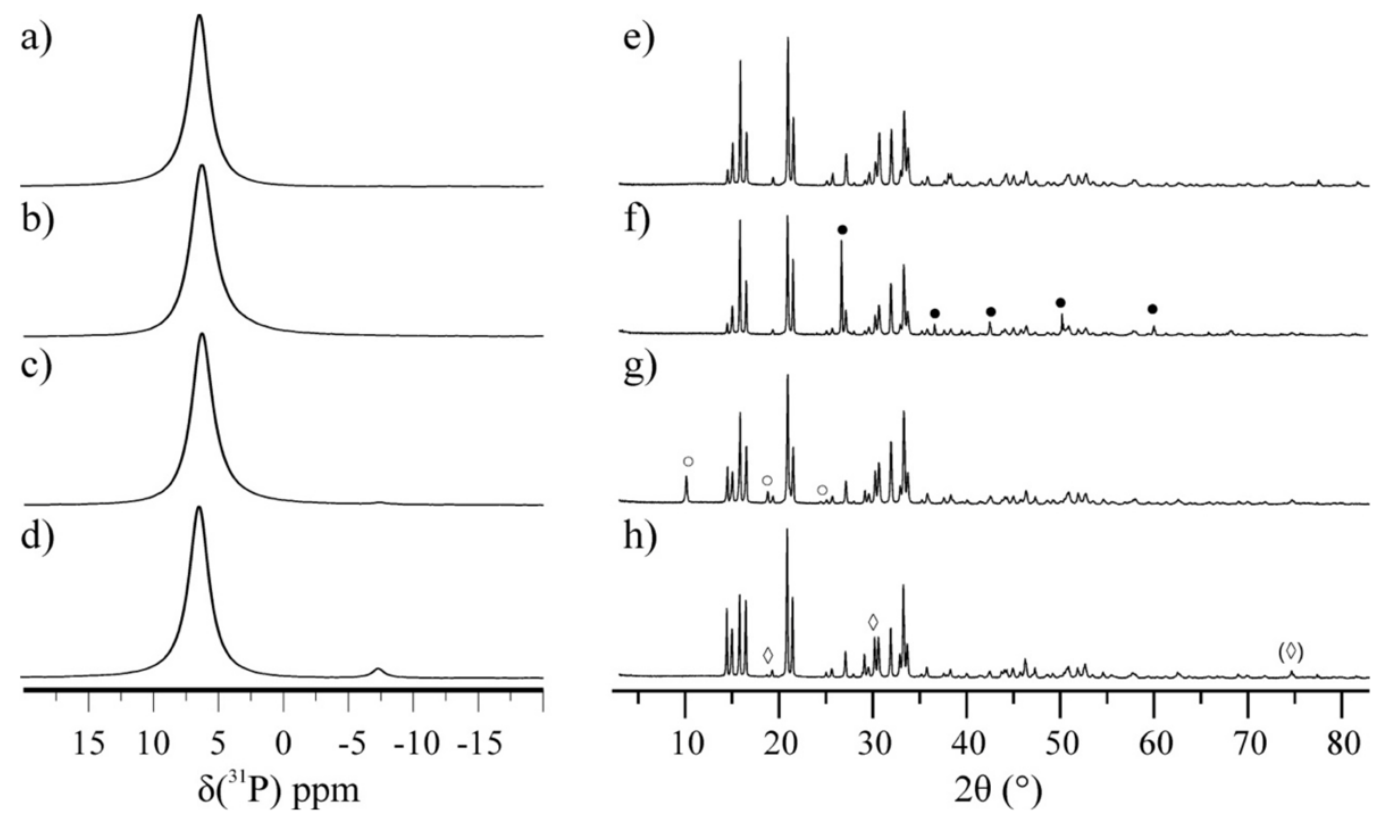

Figure 3: ${ }^{31} \mathrm{P}$ solid state NMR spectra and PXRD patterns of selected struvite products. a) SSNMR of CGL, b) SSNMR of BER, c) SSNMR of HER, d) SSNMR of HEL, e) PXRD for CGL, f) PXRD for BER, g) PXRD for HER, and h) PXRD for HEL. SSNMR: The spectra were recorded at 202.4 $\mathrm{MHz}$ with $15 \mathrm{kHz}$ spinning. PXRD reflections from impurities are marked with $\bullet$ (Berlinite), ○ (Dittmarite), and $\diamond$ (Newberyite). Additional SSNMR and PXRD data for the other samples can be found in supporting information. 


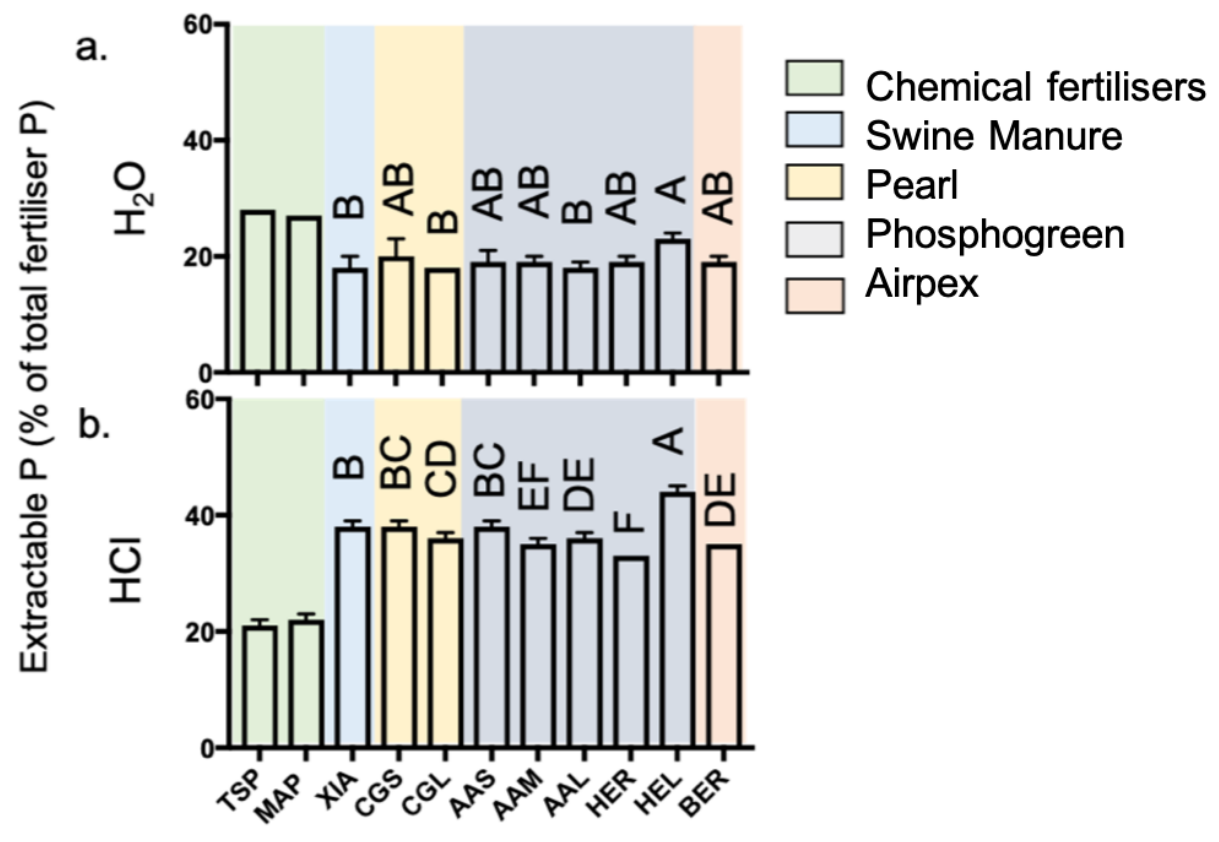

Figure 4: Extractable $\mathrm{P}$ measured from chemical solubility assays. a) $\mathrm{H}_{2} \mathrm{O}$ extraction $(P<0.05)$, b) $1 \mathrm{M} \mathrm{HCl}$ extraction $(P<0.001)$. P-values in parentheses are from GLM analysis (struvite products only), letters (A-F) within the figure refer to different grouping from Tukey pairwise comparisons. Coloured groupings denote general fertiliser type based on struvite precipitation technologies. 


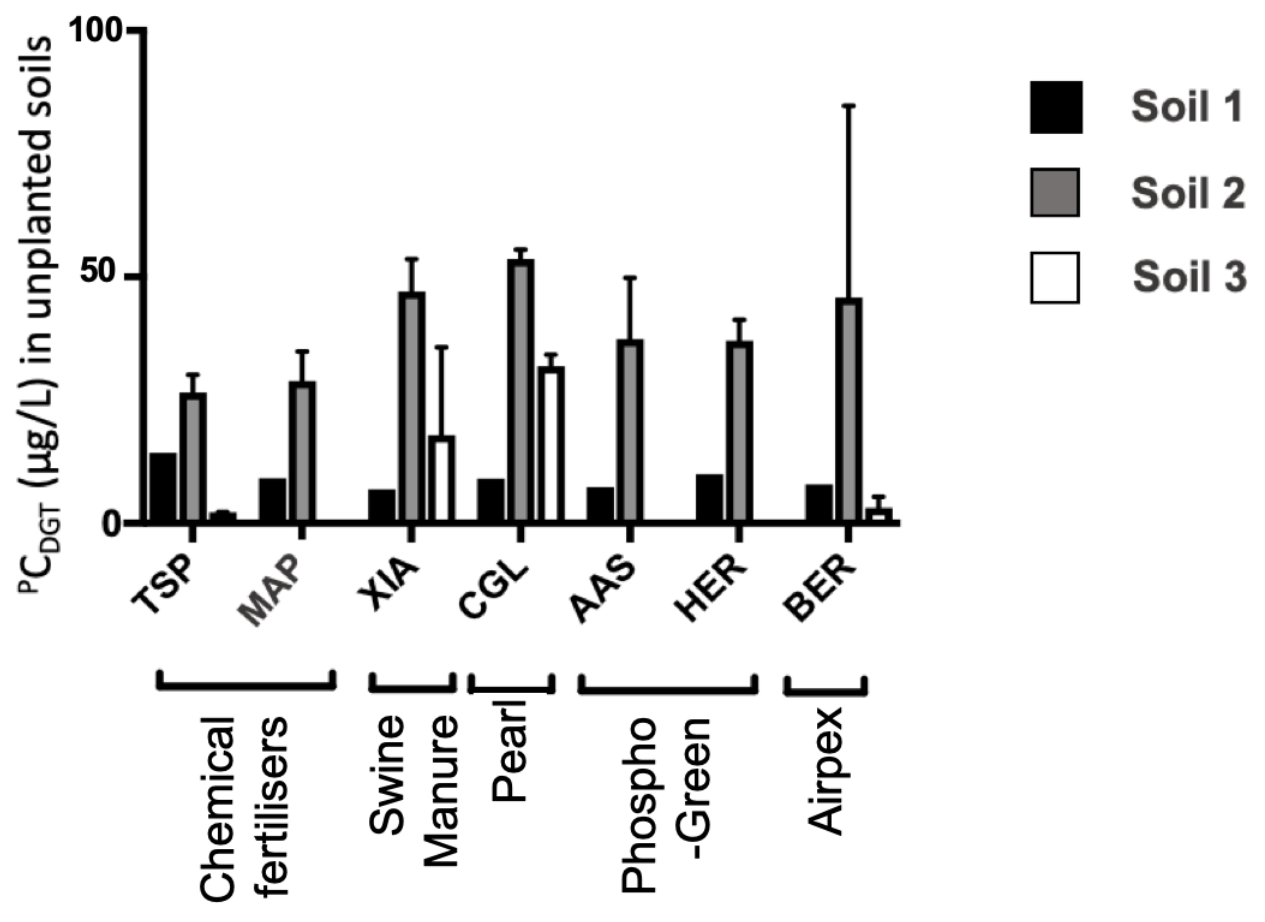

Figure 5: ${ }^{P} \mathrm{C}_{\mathrm{DGT}}$ results from the three used soils after incubation without plants for 4 weeks (soil 1) and 3 months (soils 2 and 3). GLM analysis on all the unplanted soils show there is no difference in ${ }^{P} \mathrm{C}_{\text {DGT }}$ in the unplanted soils between the struvite treatments. 

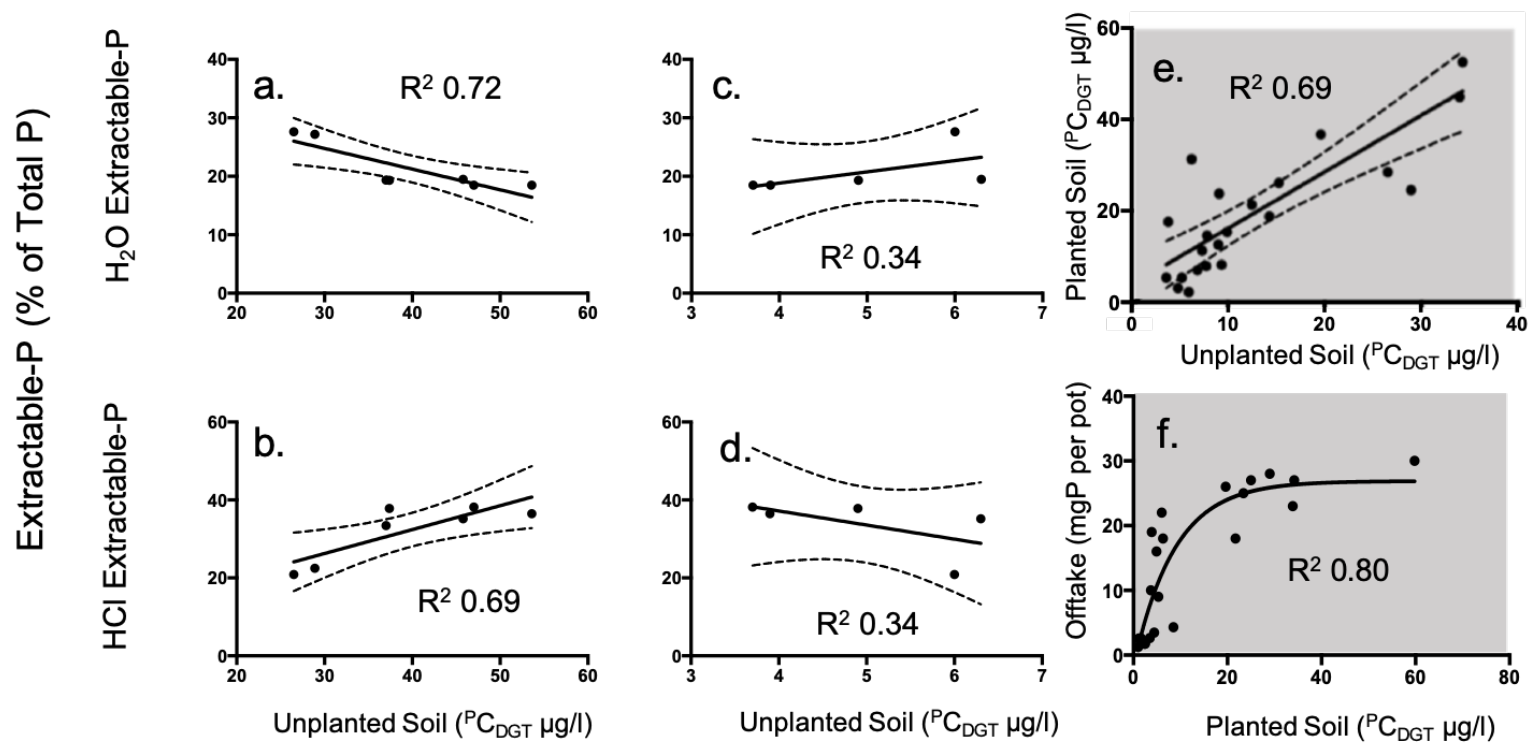

Figure 6: Fertiliser-Soil-Plant Relationships. Panels a-d: Correlations between water-extractable or acid-extractable $\mathrm{P}$ and soil ${ }^{P} \mathrm{C}_{\mathrm{DGT}}$ in incubated unplanted soil for a-b) soil 2 (control $11 \mu \mathrm{g} / \mathrm{L}$ ), c-d) soil 3 (control $1.2 \mu \mathrm{g} / \mathrm{L}$ ), e.) Planted and unplanted ${ }^{P} \mathrm{C}_{\mathrm{DGT}}$ infinite sink correlation, f) soil ${ }^{P} \mathrm{C}_{\mathrm{DGT}}$ and total $\mathrm{P}$ offtake in planted systems in $50 \mathrm{kgP} / \mathrm{Ha}$ addition (experiments $\mathrm{A}$ and $\mathrm{B}$ combined.) 

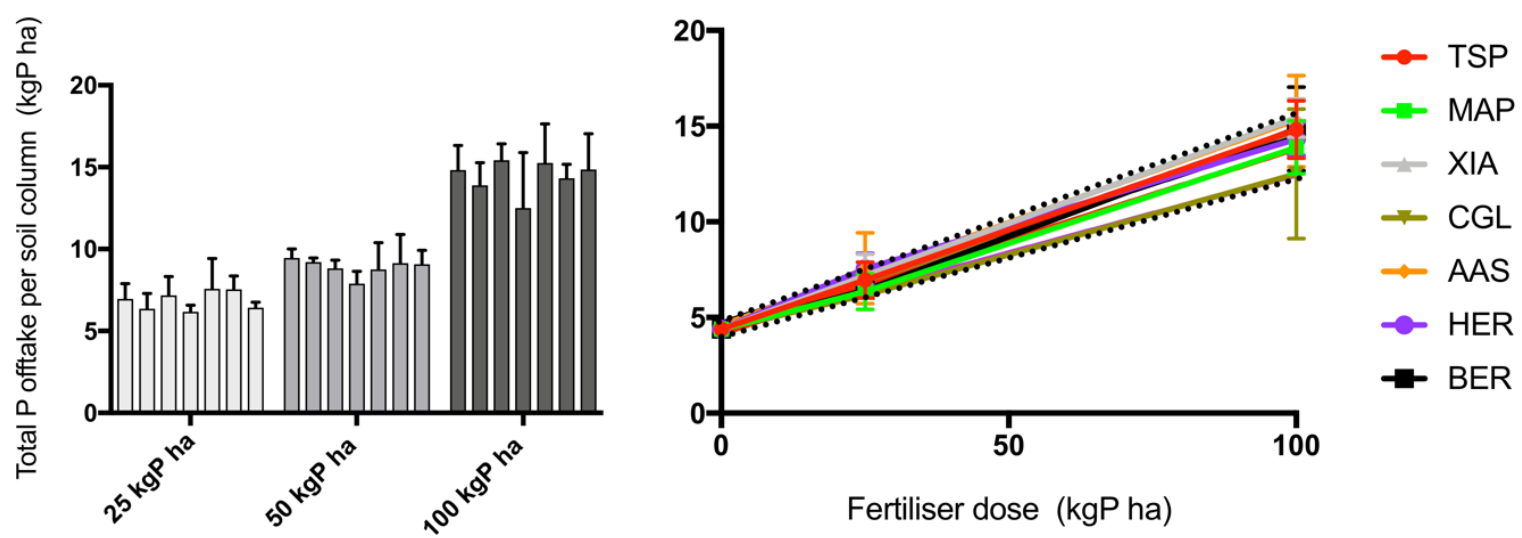

Figure 7: $\mathrm{P}$ offtake $(\mathrm{mg} / \mathrm{P})$, calculated as total $\mathrm{P}$ in shoot dry matter per Ha, over a 4-week growth trial (experiment $\mathrm{A}$ ). a. Total $\mathrm{P}$ in each soil column per treatment, $\mathrm{b}$. linear regression of dose effect for each fertiliser treatment (TSP $R^{2}=1$, MAP $R^{2}=0.99$, XIA $R^{2}=1$, CGL $R^{2}=$ 0.99 , AAS $R^{2}=0.99$, HER, $R^{2}=0.99$, BER $\left.R^{2}=0.99\right)$. $C I$. Dotted line indicates the $95 \%$ confidence interval of the TSP and MAP. 

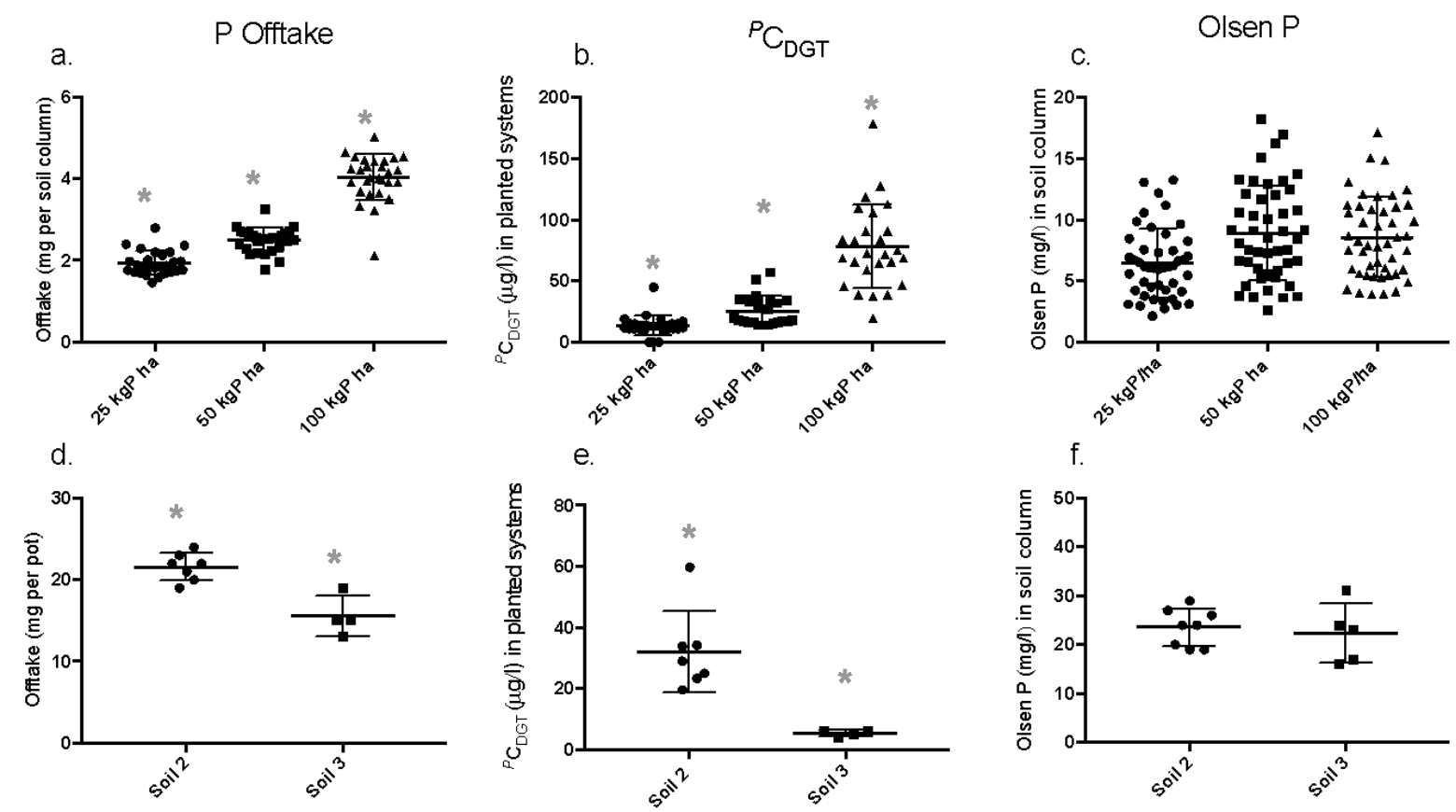

Figure 8: $\mathrm{P}$ bioavailability assays in planted systems, a) $\mathrm{P}$ offtake for shoot dry matter in experiment $\mathrm{A}, \mathrm{b})$ Soil ${ }^{P} \mathrm{C}_{\text {DGT }}$ in experiment $\mathrm{A}$, c) Soil Olsen $\mathrm{P}$ in experiment A, d) $\mathrm{P}$ offtake in shoot dry matter in experiment $\mathrm{B}$, e) Soil ${ }^{P} \mathrm{C}_{\text {DGT }}$ in experiment $\mathrm{B}$, and $\mathrm{f}$ ) Soil Olsen $\mathrm{P}$ in experiment B. Asterisks represent statistical difference in dose/soil 


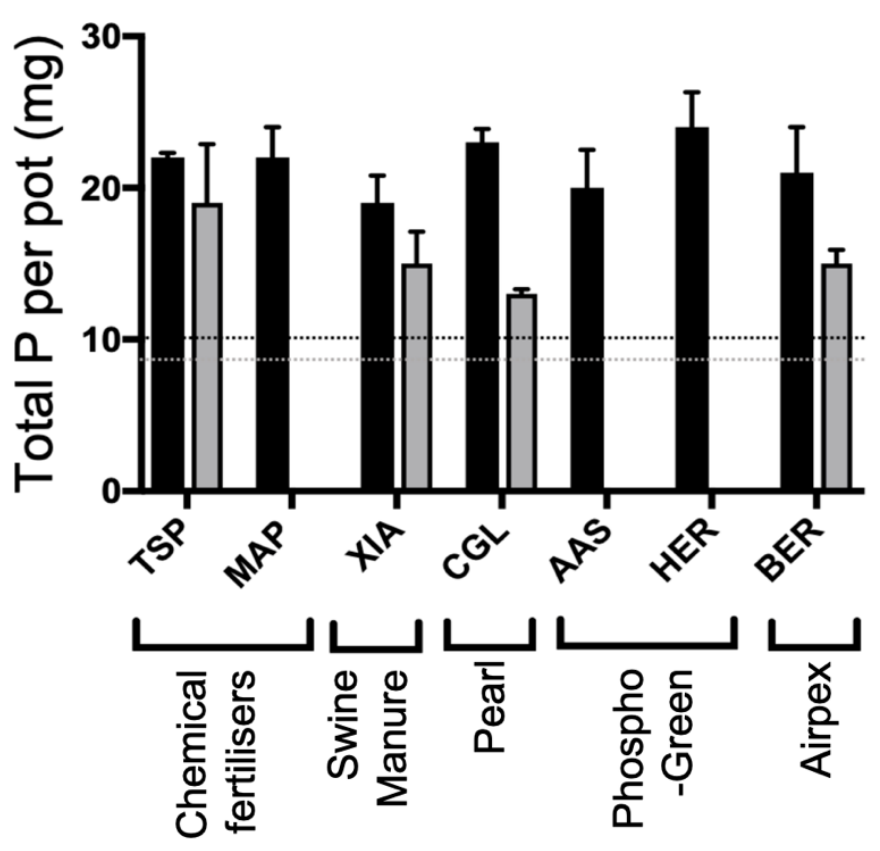

Soil 2

Soil 3

Figure 9: Total $\mathrm{P}$ ( $\mathrm{P}$ offtake) calculated as total $\mathrm{P}$ in shoot dry matter per pot over a 3-month growth trial (experiment B). Dotted line indicates P offtake in control treatment of soil 2 and 3 with no $\mathrm{P}$ addition $(10 \mathrm{~g}, 8 \mathrm{~g}$ respectively). No statistical difference is observed between the treatments $(P=>0.1)$. Soil 2 and 3 statistically different $(P=0.001)$. 

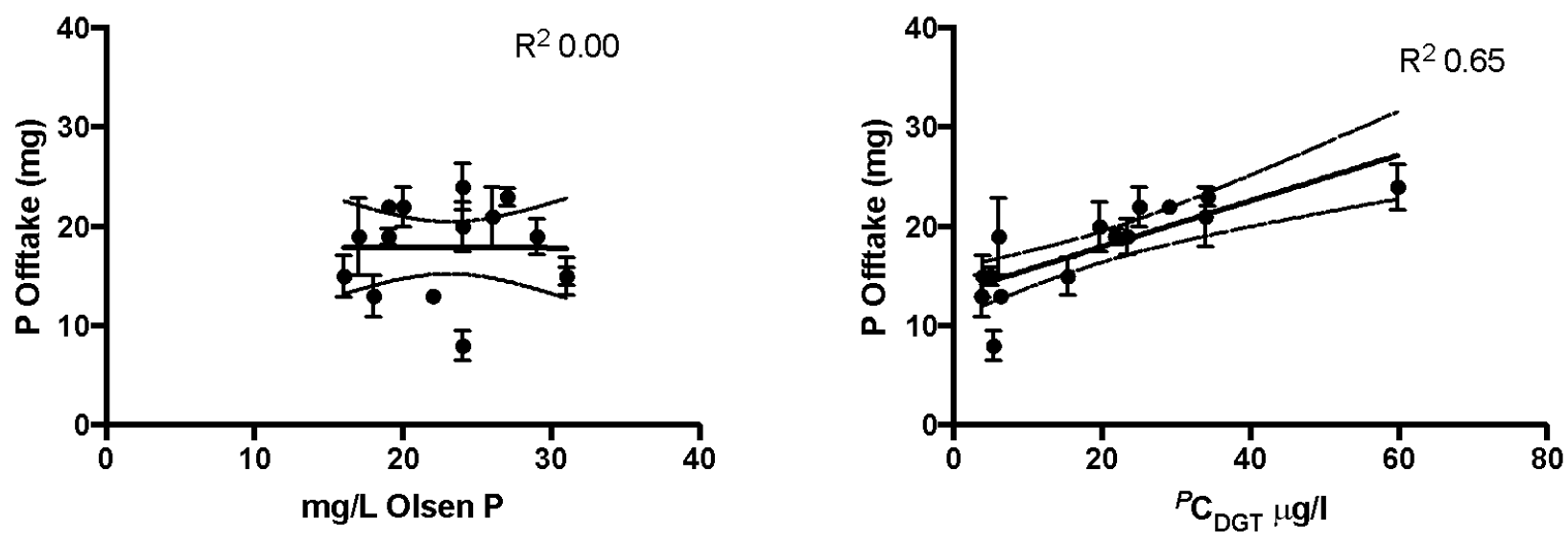

Figure 10: Correlation between $P$ offtake and soil bioavailability tests for the 3-month growth trial (experiment B). a. Olsen P and Plant P offtake $(P=>0.05)$ b. ${ }^{P} \mathrm{C}_{\mathrm{DGT}}$ and Plant offtake $(P=0.0001)$. 


\title{
Phosphorus speciation and fertiliser performance characteristics: a comparison of waste recovered struvites from global sources
}

\author{
Rebecca L. Hall, ${ }^{\mathrm{a}, \mathrm{b}, \S}$ Line Boisen Staal, ${ }^{\mathrm{c}, \S}$ Katrina A. Macintosh, ${ }^{\mathrm{a}, \mathrm{b}}$ John McGrath, ${ }^{\mathrm{a}, \mathrm{b}}$ John \\ Bailey, ${ }^{\mathrm{e}}$ Ulla Gro Nielsen, ${ }^{\mathrm{d}}$ Kasper Reitzel, ${ }^{\mathrm{b} *}$ and Paul N. Williams, ${ }^{\mathrm{a},}$
}

${ }^{a}$ Institute for Global Food Security, Queen's University Belfast, David Keir Building, Malone Road, Belfast BT9 5BN, Northern Ireland, United Kingdom

'School of Biological Sciences, 19 Chlorine Gardens, Queen's University Belfast, Belfast, BT9 5DL, United Kingdom

${ }^{\mathrm{c}}$ Department of Biology, University of Southern Denmark, Campusvej 55, DK-5230 Odense M, Denmark

${ }^{\mathrm{d}}$ Department of Physics, Chemistry and Pharmacy, University of Southern Denmark, Campusvej 55, DK-5230 Odense M, Denmark

e Agri-Food and Biosciences Institute, 18a Newforge Lane, Belfast, BT9 5PX

$\S$ These authors contributed equally 


\section{$\underline{\text { S1. Characteristics of recovered fertilisers. }}$}

The fertilisers used in this study were struvite products precipitated at wastewater treatment plants in Denmark (Herning, Aaby, and Helsingør), from pig slurry in China (Xiamen) (Chen et al. 2017, Chen et al. 2018), along with commercially available struvite products from Berliner Wasserbetriebe (Berliner Pflanze ${ }^{\mathrm{TM}}$ ) and Ostara (Crystal green $\left.{ }^{\mathrm{TM}}\right)$. At Aaby wastewater treatment plant, three different sizes of struvite pellets were produced: $1 \mathrm{~mm}, 2 \mathrm{~mm}$, and $3 \mathrm{~mm}$. Triple super phosphate (TSP), a commonly used inorganic $\mathrm{P}$ fertiliser, was used for comparison and for establishing the growth response relationship in the plant experiments between soil and $\mathrm{P}$ doses. A highly soluble monoammonium phosphate reclaimed from sewage sludge ash (cleanMAP®) EasyMining, abbreviated MAP) was included as a water-soluble, waste recovered P fertiliser. The struvite products can be seen in figure 1 and are described in table 1. The struvite products are referred to by these abbreviations: Herning (HER), Aaby small (AAS), Aaby medium (AAM), Aaby large (AAM), Helsingør (HEL), Xiamen (XIA), BerlinerPflanze ${ }^{\mathrm{TM}}$ (BER), Crystal green 1.5 mm (CGS), and Crystal green $3 \mathrm{~mm}$ (CGL).

\section{S2. Plant Experiments}

Experiment $A$. The fertiliser effect of the struvite products was tested in a highly controlled shortterm ( 4 week) experiment with ryegrass, to investigate fertiliser performance in NI soils across a range of amendment doses $(25,50$ and $100 \mathrm{mg}$ P/hectare). Early stage rhizosphere formation was induced in homogenously packed soil columns $(250 \mathrm{~g}$ soil; $10 \mathrm{~cm} \times 6.8 \mathrm{~cm})$, by transplanting a standardised seedlings biomass (ca. 25 plants, 4 replicates of each treatment) to create a uniform environment to isolate plant-soil-fertiliser interactions.

Ryegrass seeds were germinated on rock wool in a hydroponic growth system in a greenhouse, and after a month the seedlings were transplanted into soil-filled pots amended with different 
fertilisers and then grown in a controlled environment growth chamber for four weeks. Perennial Ryegrass (AberMagic high sugar diploid: Morton's, Hillsborough ） was germinated in rockwoolsupported hydroponics system (Växer from IKEA) in a greenhouse using a $1 / 4$ strength Hoagland solution (Supporting information page S3). $2 \mathrm{~g}$ (wet weight) of healthy seedlings were removed from the hydroponic system at four weeks and used for transplanting.

The recommended P fertiliser level for grass establishment on NI soils with P-index 0 (Olsen-P 0-9 mgP/kg soil) is $120 \mathrm{~kg} \mathrm{P}_{2} \mathrm{O}_{5} / \mathrm{ha}$, corresponding to $52.3 \mathrm{kgP} / \mathrm{ha}$ (AHDB 2018). struvite products and clean MAP were ground and added at three levels: The recommended level (50 $\mathrm{kgP} / \mathrm{ha}$, corresponding to $73 \mathrm{mgP} /(\mathrm{kg}$ dry soil) $)$, a low level $(25 \mathrm{kgP} / \mathrm{ha}$, corresponding to 36 $\mathrm{mgP} /(\mathrm{kg}$ dry soil)) and a high level (100 kgP/ha, corresponding to $146 \mathrm{mgP} /(\mathrm{kg}$ dry soil $))$. Ground TSP was added at five levels and served as a control response curve with the following doses: 0 $\mathrm{kgP} / \mathrm{ha}, 12.5 \mathrm{kgP} / \mathrm{ha}, 25 \mathrm{kgP} / \mathrm{ha}, 50 \mathrm{kgP} / \mathrm{ha}$, and $100 \mathrm{kgP} / \mathrm{ha}$. The fertilisers were dosed based on their total $\mathrm{P}$ content to ensure that all pots received the same amount of total $\mathrm{P}$.

Each soil batch was prepared in the same way: $250 \mathrm{~g}$ of dry soil (sieved to $<2 \mathrm{~mm}$ ) was mixed with a corresponding addition of $\mathrm{P}$ fertiliser (Table $\mathrm{S} 1$ ), along with a replete supply of $\mathrm{N}$ in the form of $125 \mathrm{mg}$ urea. $\mathrm{N}$ dosing was undertaken to standardise the experimental conditions and to isolate the impact of P uptake by the plants. Soils were shaken using a VWR Multi-Tube Vortexer for 10 min and wetted to $65 \% \mathrm{WHC}$, the soil was then incubated for four days and packed to a bulk density of $\sim 1.3 \mathrm{~g} / \mathrm{cm}^{3}$ in the cylindrical PVC soil columns (washed in $7 \%$ nitric acid). Planted soil columns were watered every $5 / 7$ days and kept at $65 \%$ WHC using a capillary action watering method throughout the 4 week growth period. 
The controlled environment growth chamber was kept at $20^{\circ} \mathrm{C}$ with a 16 hour day-light period. Each planted pot had 4 replicates in a randomised block design, with pots in each blockrotated every 5/7 days. An additional pot without plants was watered alongside the planted treatments throughout the growth period to provide information on only soil chemistry/solubility between treatments in the absence of plants.

Grass samples were harvested by cutting the plant shoot and dried at $65^{\circ} \mathrm{C}$ until completely dry. Dry Matter (DM) yields were then obtained by weighing the dried shoot material. Plant shoots were then ground at $500 \mathrm{rpm}$ for 5-8 minutes in a Retsch PM100 ball mill using porcelain grinding equipment.

Table S1a. Fertiliser addition to each soil column (Experiment A)

\begin{tabular}{ccccc}
\hline $\begin{array}{c}\text { Fertiliser } \\
\text { Treatment }\end{array}$ & $\begin{array}{c}\text { Total P }(\mathrm{mg} / \mathrm{g}) \\
\text { ICP-OES }\end{array}$ & $\begin{array}{c}\text { Low dose } \\
(\mathrm{g})\end{array}$ & $\begin{array}{c}\text { Medium dose } \\
(\mathrm{g})\end{array}$ & $\begin{array}{c}\text { High dose } \\
(\mathrm{g})\end{array}$ \\
\hline TSP & 213 & 0.0427 & 0.0855 & 0.1709 \\
MAP & 275 & 0.0332 & 0.0664 & 0.1327 \\
XIA & 135 & 0.0673 & 0.1346 & 0.2693 \\
CGL & 131 & 0.0694 & 0.1388 & 0.2776 \\
AAS & 134 & 0.0682 & 0.1364 & 0.2727 \\
HER & 129 & 0.0709 & 0.1418 & 0.2835 \\
BER & 90 & 0.1013 & 0.2027 & 0.1709 \\
\hline
\end{tabular}


Table S1b. Fertiliser addition to each soil pot (Experiment B)

\begin{tabular}{ccc}
\hline $\begin{array}{c}\text { Fertiliser } \\
\text { Product }\end{array}$ & $\begin{array}{c}\text { Total P }(\mathrm{mg} / \mathrm{g}) \\
\text { ICP-OES }\end{array}$ & $\begin{array}{c}\text { Medium Dose } \\
(\mathrm{g})\end{array}$ \\
\hline TSP & 213 & 1.71 \\
MAP & 275 & 1.33 \\
XIA & 135 & 2.69 \\
CGL & 131 & 2.78 \\
AAS & 134 & 2.73 \\
HER & 129 & 2.84 \\
BER & 90 & 4.05 \\
\hline
\end{tabular}



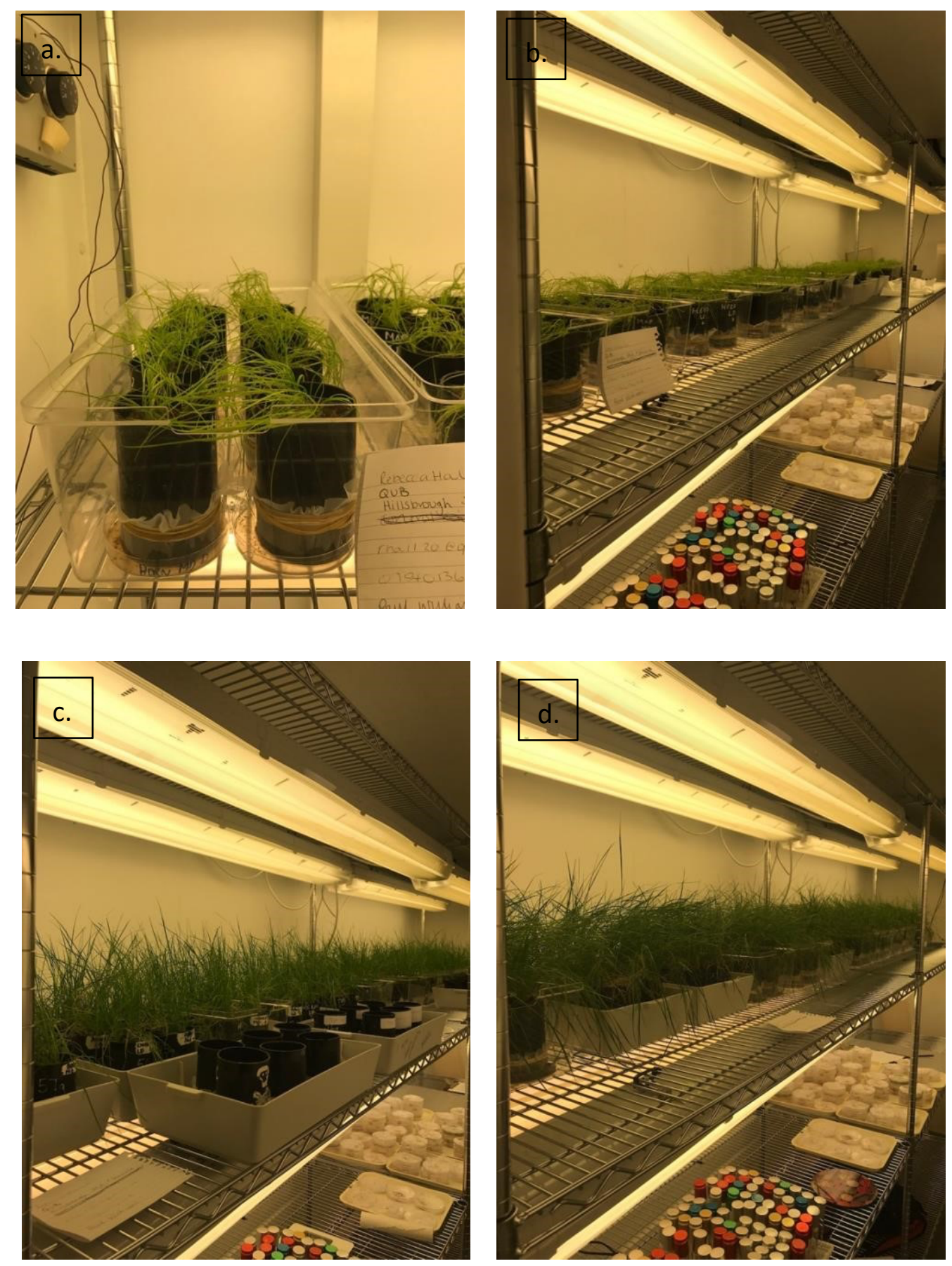

Figure S1. Photos of plant Experiment A. a-b. Day 1 in growth chamber, c. Week 2 in growth chamber, d. week 4 in growth chamber. 
Experiment $B$. The 4-week screening experiment was followed-up by a 3 month greenhouse/pot trial ( $5 \mathrm{~kg}$ soil; $30 \mathrm{~cm} \times 25 \mathrm{~cm}, \mathrm{n}=3$ ) where the different struvites were interrogated using two NI soils of different pH (BE3M: 6.2 and MG3M), to consider plant growth over longer timeframes.

Soils were treated with a fertiliser dose of $50 \mathrm{kgP} /$ ha and equivalent $\mathrm{N}$ (Urea). BE3M was treated with the same fertilisers as the 4-week ryegrass experiment (No P addition, TSP, MAP, XIA, CGL, AAS, HER, BER) where MG3M was only treated with commercially available fertilisers TSP, XIA, CGL, BER and a control treatment with no P addition. Fertilisers were applied to the top layer of soil and then mixed by hand to get a homogeneous distribution. Soils were left to equilibrate for four days after and kept at $65 \%$ WHC throughout the experimental procedure, ryegrass germination experimental procedures from the 4-week screening were followed with $20 \mathrm{~g}$ of wet biomass transferred into the soil (sieved $<2 \mathrm{~mm}$ ). A growth period of 3 month was carried out with assisted heat lighting from $8 \mathrm{am}-8 \mathrm{pm}$. Ryegrass shoots and soils were harvested and treat with same protocol from experiment A. 

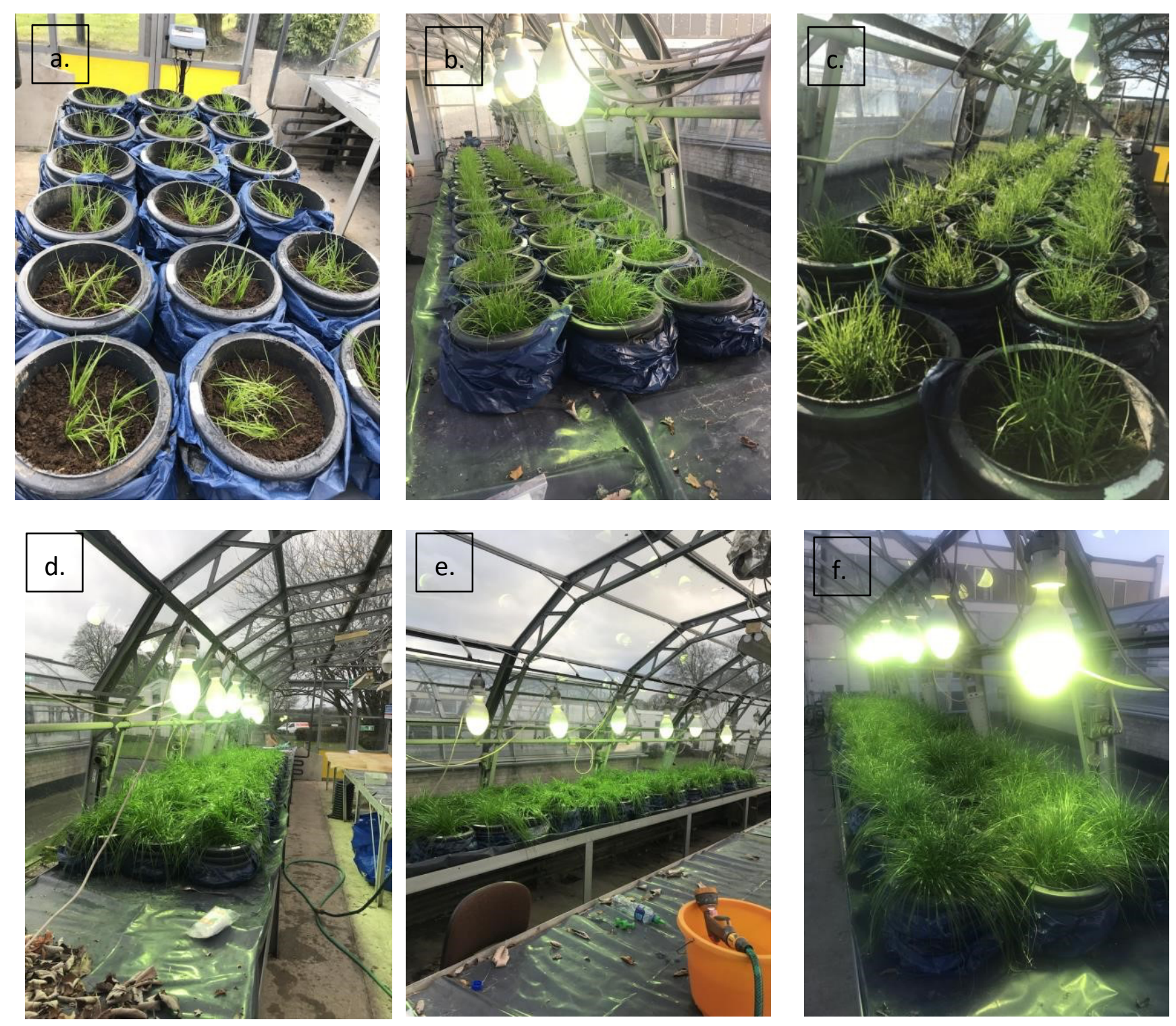

Figure S2. Photos of plant Experiment B. a. Day 1 in greenhouse, b. Week 2 in greenhouse, c. week 3 in greenhouse, d-e. week 9 in greenhouse, f. week 12 in greenhouse. 
Table S2. Comparison of Experiment A and B

\begin{tabular}{|c|c|c|}
\hline & Experiment A & Experiment B \\
\hline Objective & $\begin{array}{l}\text { Fertiliser performance across } \\
\text { a range of amendment doses } \\
\left(25,50 \text { and } 100 \mathrm{~kg} \mathrm{P} \mathrm{ha}^{-1}\right) .\end{array}$ & $\begin{array}{l}\text { Plant growth and plant-soil- } \\
\text { fertiliser interactions over a } \\
\text { longer time using two soils of } \\
\text { different } \mathrm{pH} \text { (Soil } 2: 6.2 \text { /Soil } \\
3: 5.4 \text { ) }\end{array}$ \\
\hline Duration of experiment & 4 weeks & 3 month \\
\hline $\begin{array}{c}\text { Environmental } \\
\text { conditions }\end{array}$ & $\begin{array}{l}\text { Controlled environment } \\
\text { growth chamber }\end{array}$ & Greenhouse with heat lamps \\
\hline Soils used & Soil 1: Brown Earth, pH 4.8 & $\begin{array}{l}\text { Soil 2: Brown Earth, pH } 6.2 \\
\text { Soil 3: Mineral Gley, pH } 5.4\end{array}$ \\
\hline Pot size/soil weight & $\begin{array}{l}250 \mathrm{~g} \text { soil; } 10 \mathrm{~cm} \times 6.8 \mathrm{~cm}, \\
\mathrm{n}=4\end{array}$ & $5 \mathrm{~kg}$ soil; $30 \mathrm{~cm} \times 25 \mathrm{~cm}, \mathrm{n}=3$ \\
\hline $\begin{array}{l}\text { Seedling Biomass } \\
\text { transfer }\end{array}$ & $2 \mathrm{~g}$ wet biomass & $20 \mathrm{~g}$ wet biomass \\
\hline Watering regime & $5 / 7$ days $(65 \%$ WHC) & 2/7 days $(65 \% \mathrm{WHC})$ \\
\hline
\end{tabular}




\section{S3. Nutrient solutions for hydroponic nursery systems}

A) $812 \mathrm{mM} \mathrm{KNO}_{3}, 500 \mathrm{mM} \mathrm{Ca}\left(\mathrm{NO}_{3}\right)_{2} \cdot 4 \mathrm{H}_{2} \mathrm{O}$.

B) $250 \mathrm{mM} \mathrm{NH} \mathrm{H}_{2} \mathrm{PO}_{4}, 250 \mathrm{mM} \mathrm{MgSO} 4 \cdot 7 \mathrm{H}_{2} \mathrm{O}$.

C) $4.6 \mathrm{mM} \mathrm{H}_{3} \mathrm{BO}_{3}, 0.5 \mathrm{mM} \mathrm{MnCl}_{2} \cdot 4 \mathrm{H}_{2} \mathrm{O}, 0.2 \mathrm{mM} \mathrm{ZnSO} \cdot 7 \mathrm{H}_{2} \mathrm{O}, 0.1 \mathrm{mM}\left(\mathrm{NH}_{4}\right)_{6} \mathrm{Mo}_{7} \mathrm{O}_{24} \cdot 4 \mathrm{H}_{2} \mathrm{O}$, $0.2 \mathrm{mM} \mathrm{CuSO}_{4} \cdot 5 \mathrm{H}_{2} \mathrm{O}$. D) $45 \mathrm{mM} \mathrm{NaFeEDTA.}$

For each $5 \mathrm{~L}$ of diluted Hoagland, $10 \mathrm{~mL}$ of A, $10 \mathrm{~mL}$ of B, $1.25 \mathrm{~mL}$ of C, and $1.25 \mathrm{~mL}$ of $\mathrm{D}$ were used. This means that the diluted Hoagland solution that was used for the plants consisted of: 1.625 $\mathrm{mM} \mathrm{KNO} 3,1.0 \mathrm{mM} \mathrm{Ca}\left(\mathrm{NO}_{3}\right)_{2} \cdot 4 \mathrm{H}_{2} \mathrm{O}, 0.5 \mathrm{mM} \mathrm{NH} \mathrm{H}_{2} \mathrm{PO}_{4}, 0.5 \mathrm{mM} \mathrm{MgSO} \cdot 7 \mathrm{H}_{2} \mathrm{O}, 1.15 \mu \mathrm{M}$ $\mathrm{H}_{3} \mathrm{BO}_{3}, 0.125 \mu \mathrm{M} \mathrm{MnCl}_{2} \cdot 4 \mathrm{H}_{2} \mathrm{O}, 0.05 \mu \mathrm{M} \mathrm{ZnSO}_{4} \cdot 7 \mathrm{H}_{2} \mathrm{O}, 0.025 \mu \mathrm{M}\left(\mathrm{NH}_{4}\right)_{6} \mathrm{Mo}_{7} \mathrm{O}_{24} \cdot 4 \mathrm{H}_{2} \mathrm{O}, 0.05 \mu \mathrm{M}$ $\mathrm{CuSO}_{4} \cdot 5 \mathrm{H}_{2} \mathrm{O}, 11.25 \mu \mathrm{M}$ NaFeEDTA.

Nutrient solution applied first on day $8\left(13^{\text {th }}\right.$ Oct $)$ after seeding $\left(5^{\text {th }}\right.$ Oct $)$ and then changed every four-six days $\left(17^{\text {th }}, 23^{\text {th }}\right.$ and $27^{\text {th }}$ Oct $)$. The stock solutions were made from distilled water, dilution made with tap water. 


\section{S4. Elemental analysis}

In order to determine the $\mathrm{P}$ content of the struvite products for dosing of struvite in the plant experiment, and to investigate the metal composition of the struvites, elemental analysis by was performed using inductively coupled plasma optical emission spectroscopy (ICP-OES, Perkin Elmer Optima 2100 DV). Total P and metals were measured on fertiliser samples which had been microwave digested in concentrated $\mathrm{HNO}_{3}\left(0.1 \mathrm{~g}\right.$ sample in $\left.6 \mathrm{~mL} \mathrm{HNO}_{3}\right)$. The samples were measured in radial mode at the following wavelengths: Al $(396.153 \mathrm{~nm}), \mathrm{Ca}(317.933 \mathrm{~nm}), \mathrm{Cd}$ (228.803 nm), Cr (267.716 nm), Cu (327.393 nm), Fe (238.204 nm), Mg (285.213 nm), Mn (257.610 nm), Ni (231.604 nm), P (213.617 nm), Pb (220.353 nm), Zn (206.200 nm). SCP science PlasmaCAL Water and Wastewater (Alternate metals I, II) were used for quality control.

${ }^{31} \mathrm{P}$ magic angle spinning solid state NMR spectroscopy. Solid state ${ }^{31} \mathrm{P}$ NMR spectroscopy was performed at $11.7 \mathrm{~T}$ on a $500 \mathrm{MHz}$ Jeol ECZ 500R spectrometer with a $3.2 \mathrm{~mm}$ Jeol MAS NMR probe. Quantitative ${ }^{31} \mathrm{P}$ MAS NMR spectra ( $45^{\circ}$ flip angle) were recorded for all fertiliser samples with $15 \mathrm{kHz}$ magic angle spinning (MAS). The carrier frequency was set at $-9 \mathrm{ppm}$. The recycle delay was optimized for each sample and set to $5 \cdot \mathrm{T}_{1}$ for the $\mathrm{P}$ signal in the sample with longest relaxation, as determined from inversion recovery experiments. Typical recycle delays chosen were $130-800$ seconds. Spectra were referenced to $\mathrm{H}_{3} \mathrm{PO}_{4}\left(\delta\left({ }^{31} \mathrm{P}\right)=0 \mathrm{ppm}\right)$, and single-pulse ${ }^{31} \mathrm{P}$ SSNMR spectra were analysed by absolute integration of the resonances in MestReNova after baseline correction. When spinning side bands were present, they were included in the integration of the signals. 
Powder X-Ray diffraction. PXRD diffractograms were recorded on a Rigaku Miniflex 600 diffractometer using CuKa radiation $(\lambda=1.5418 \AA)$. The data were recorded in the range $2 \theta=3$ $90^{\circ}$ with a step size of 0.02 and a speed $10^{\circ} / \mathrm{min}$. The software PDXL2 from

Rigaku was used to match diffractograms with the ICDD library. 


\section{$\underline{\text { S5 Elemental composition of fertiliser samples }}$}

Table S2: $\mathrm{P}$ and $\mathrm{Mg}$ concentrations in the fertiliser samples (\%) as measured by ICPOES. Standard deviation in parenthesis.

\begin{tabular}{|c|c|c|}
\hline Sample & $\mathbf{P}$ & Mg \\
\hline TSP & $21.4(0.2)$ & $0.5(0.0)$ \\
\hline HER & $13.2(0.5)$ & $10.5(0.4)$ \\
\hline AAS & $12.2(1.6)$ & $10.0(1.6)$ \\
\hline $\mathbf{A A M}$ & $13.6(0.04)$ & $11.0(0.1)$ \\
\hline $\mathbf{A A L}$ & $13.5(0.1)$ & $10.7(0.03)$ \\
\hline CGL & $13.4(0.5)$ & $10.3(0.4)$ \\
\hline CGS & $13.2(0.2)$ & $10.8(0.2)$ \\
\hline XIA & $12.6(0.4)$ & $10.7(0.5)$ \\
\hline BER & $9.0(0.2)$ & $7.7(0.1)$ \\
\hline HEL & $10.9(0.04)$ & $9.5(0.2)$ \\
\hline MAP & $22.9(3.2)$ & $0.0(0.0)$ \\
\hline
\end{tabular}


Table S3: Metal concentrations $(\mathrm{mg} / \mathrm{kg})$ as measured by ICP-OES, numbers in parenthesis are standard deviation. Samples were measured by microwave digestion in concentrated $\mathrm{HNO}_{3}(0.1$ $\mathrm{g}$ sample in $6 \mathrm{~mL} \mathrm{HNO}_{3}$ ).

\begin{tabular}{ccccccccccc}
\hline Sample & Al & Fe & Ca & Cu & Cr & Cd & Zn & Ni & Pb & Mn \\
\hline TSP & $2001(19)$ & $1031(18)$ & $187063(97)$ & $35(0.8)$ & $131(0.7)$ & $23(0.2)$ & $502(8)$ & $38(0.1)$ & $<1$ & $21(0.03)$ \\
HER & $33(1)$ & $1349(8)$ & $1063(43)$ & $3(0.5)$ & $3(0.5)$ & $<1$ & $14(0.3)$ & $<1$ & $<1$ & $196(8)$ \\
AAS & $<1$ & $215(24)$ & $246(31)$ & $1(0.1)$ & $3(0.4)$ & $<1$ & $2(0.4)$ & $<1$ & $<1$ & $48(7)$ \\
AAM & $<1$ & $99(0.4)$ & $708(6)$ & $<1$ & $3(0.01)$ & $<1$ & $<1$ & $<1$ & $<1$ & $18(0.1)$ \\
AAL & $<1$ & $120(0.5)$ & $599(4)$ & $<1$ & $3(0.1)$ & $<1$ & $<1$ & $<1$ & $<1$ & $51(1)$ \\
CGL & $<1$ & $208(9)$ & $646(40)$ & $<1$ & $3(0.02)$ & $<1$ & $<1$ & $<1$ & $<1$ & $12(0.4)$ \\
CGS & $<1$ & $290(11)$ & $553(0.2)$ & $<1$ & $3(0.3)$ & $<1$ & $<1$ & $<1$ & $<1$ & $12(0.1)$ \\
XIA & $2(2)$ & $10(3)$ & $1096(49)$ & $<1$ & $3(0.1)$ & $<1$ & $1(0.05)$ & $1(0.1)$ & $<1$ & $8(0.3)$ \\
BER & $432(6)$ & $2993(141)$ & $6823(77)$ & $55(12)$ & $5(0.5)$ & $<1$ & $90(3)$ & $5(3)$ & $14(5)$ & $96(5)$ \\
MAP & $2(3)$ & $5(0.4)$ & $70(0.7)$ & $3(0.7)$ & $6(0.8)$ & $<1$ & $1(2)$ & $<1$ & $<1$ & $<1$
\end{tabular}



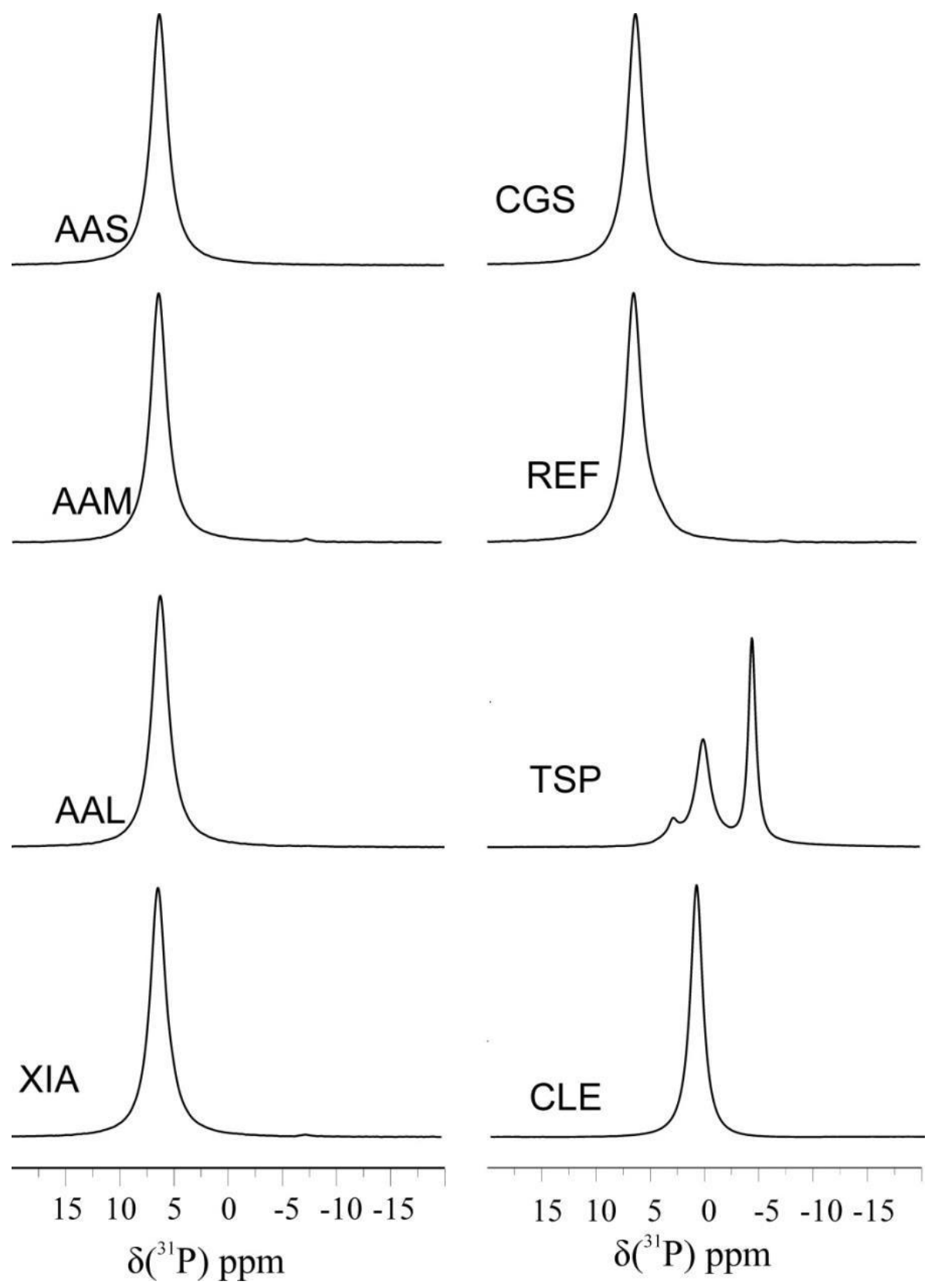

Figure S3: ${ }^{31} \mathrm{P}$ MAS SSNMR spectra of fertiliser samples. ${ }^{31} \mathrm{P}$ MAS SSNMR spectra for samples CGL, HER, HEL, and BER can be found in the main article. 


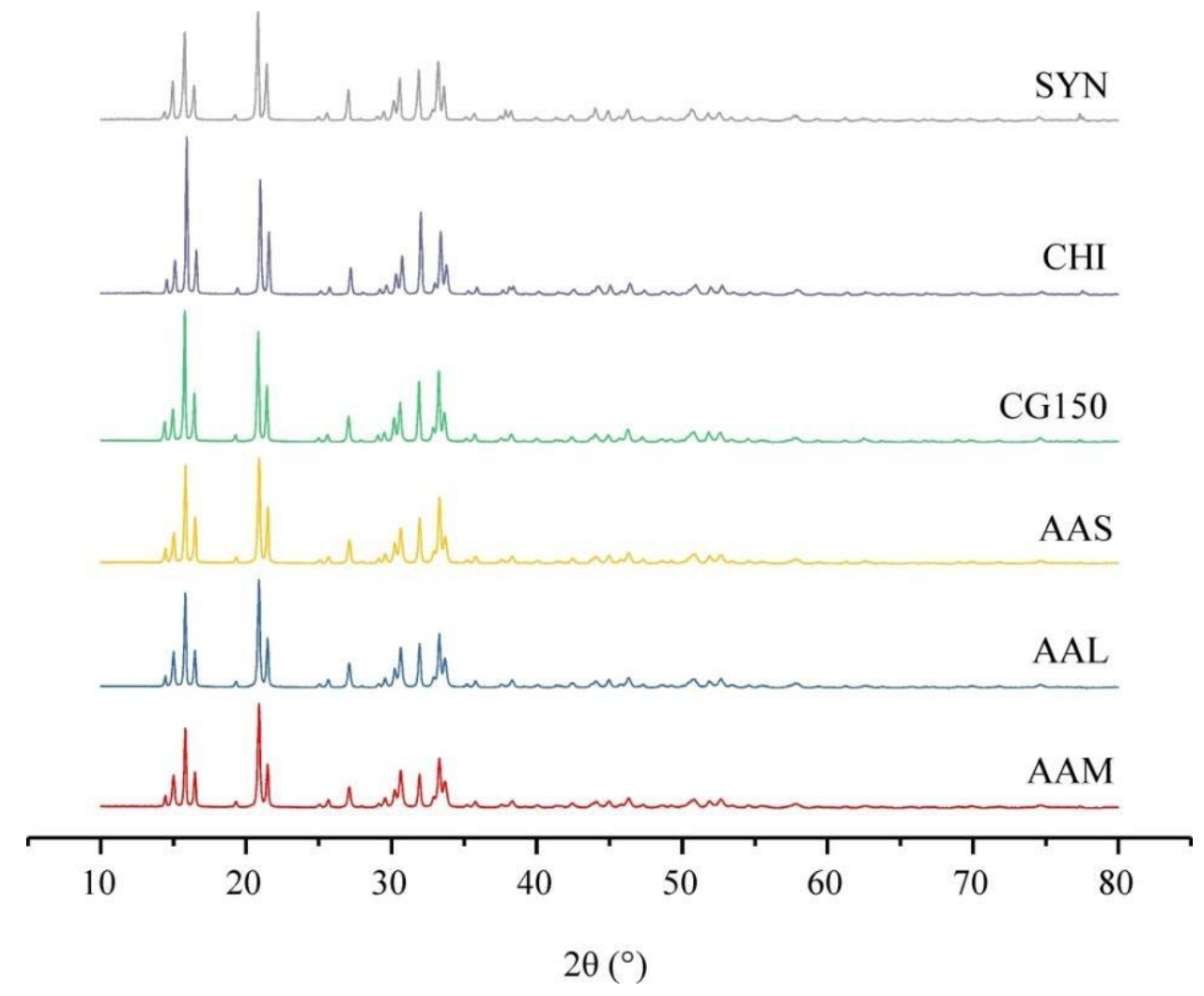

Figure S4: PXRD of struvite products. All match reference pattern for struvite (ICDD no. 01-0772303). PXRD data for samples CGL, HER, HEL, and BER can be found in the main article. 

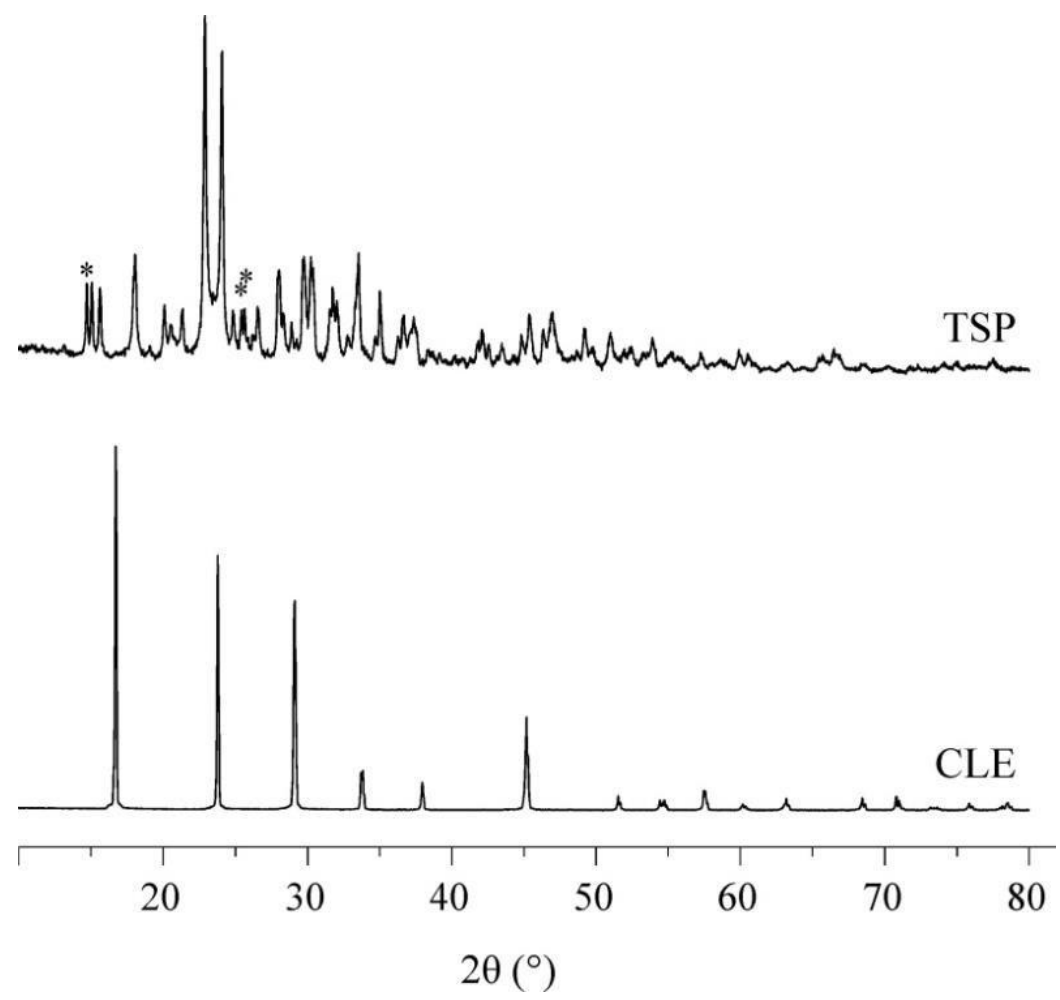

Figure S5: PXRD for the TSP and MAP samples, which match reference pattern for $\mathrm{CaH}_{2} \mathrm{PO}_{4} \cdot \mathrm{H}_{2} \mathrm{O}$ (ICDD no. 01-075-1521) and $\mathrm{NH}_{4} \mathrm{H}_{2} \mathrm{PO}_{4}$ (ICDD no. 01-072-4581),

respectively. Asterisks indicate reflections from the impurity basanite $\left(\mathrm{CaSO}_{4} \cdot 0.5 \mathrm{H}_{2} \mathrm{O}, \mathrm{ICDD}\right.$ no. 00-037-0246). 
TSP

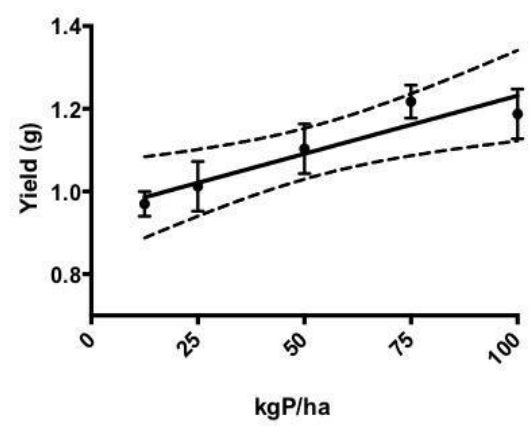

HER

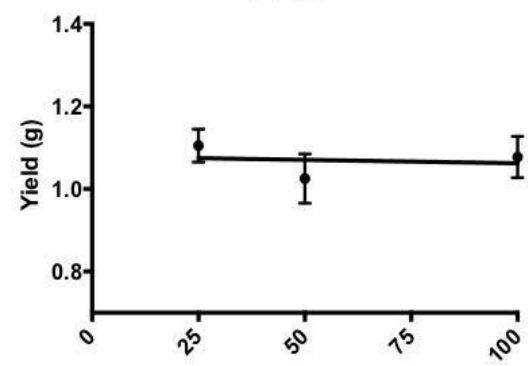

BER

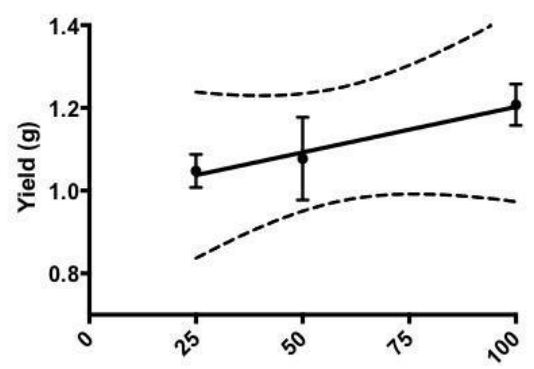

XIA

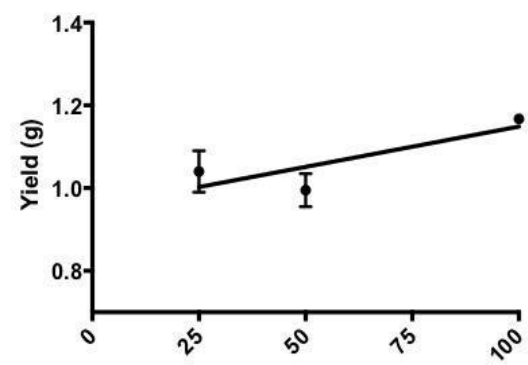

CLE

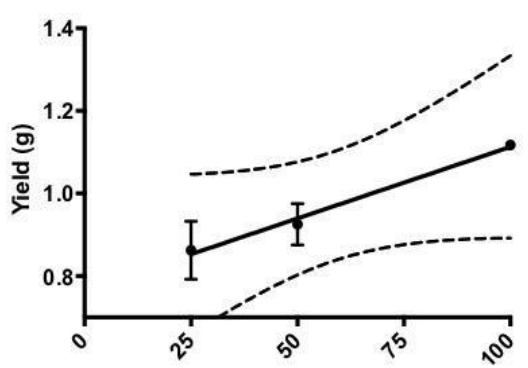

AAS

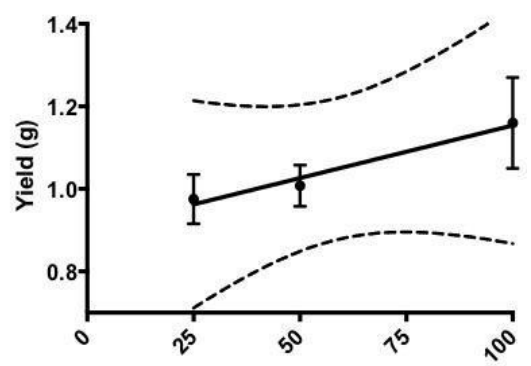

CGL

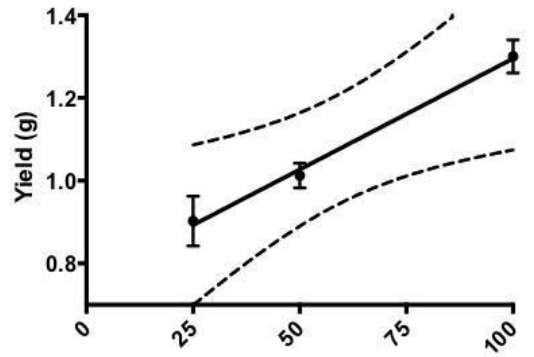

Figure S7: Biomass $(\mathrm{g})$ response to fertiliser dose $(\mathrm{kgP} / \mathrm{ha})$ for different fertiliser products. $\mathrm{R}^{2}$ values: 0.88 (TSP), 0.99 (MAP), 0.02 (HER), 0.97 (AAS), 0.96 (BER), 0.99 (CGL), 0.69 (XIA). 
Table S4: Nutrient content of harvested plant material from ICP-OES analysis.

\begin{tabular}{|c|c|c|c|c|c|c|c|c|c|c|c|c|c|}
\hline \multicolumn{2}{|c|}{$\begin{array}{c}\text { Amendment } \\
\mathrm{KgP} / \mathrm{Ha}\end{array}$} & \multicolumn{2}{|l|}{$\mathbf{N}$} & \multicolumn{2}{|r|}{$\mathbf{P}$} & \multicolumn{2}{|c|}{$\mathbf{K}$} & \multicolumn{2}{|c|}{$\mathrm{Ca}$} & \multicolumn{2}{|c|}{ Mg } & \multicolumn{2}{|c|}{$\mathbf{S}$} \\
\hline & $\mathbf{0}$ & 3.89 & $(0)$ & 0.13 & $(-0.01)$ & 1.8 & $(0.09)$ & 0.27 & $(0.03)$ & 0.2 & $(0.02)$ & 0.29 & $(0.01)$ \\
\hline \multirow{5}{*}{ TSP } & 12.5 & 3.76 & $(0)$ & 0.16 & $(0.02)$ & 1.63 & $(0.19)$ & 0.295 & $(0.02)$ & 0.2 & $(0.02)$ & 0.28 & $(0.04)$ \\
\hline & 25 & 3.72 & $(0)$ & 0.19 & $(0.02)$ & 1.56 & $(0.11)$ & 0.318 & $(0.03)$ & 0.2 & $(0.01)$ & 0.28 & $(0.02)$ \\
\hline & 50 & 3.62 & $(0)$ & 0.24 & $(0.02)$ & 1.34 & $(0.13)$ & 0.329 & $(0.03)$ & 0.2 & $(0.01)$ & 0.27 & $(0.03)$ \\
\hline & 75 & 3.5 & $(0)$ & 0.24 & $(0.01)$ & 1.27 & $(0.04)$ & 0.308 & $(0.04)$ & 0.2 & $(0.02)$ & 0.24 & $(0.03)$ \\
\hline & 100 & 3.81 & $(0)$ & 0.35 & $(0.03)$ & 1.34 & $(0.17)$ & 0.346 & $(0.01)$ & 0.2 & $(0.01)$ & 0.3 & $(0.04)$ \\
\hline \multirow{3}{*}{ MAP } & 25 & 4.03 & (0) & 0.21 & $(0.01)$ & 1.66 & $(0.15)$ & 0.321 & $(0.01)$ & 0.2 & $(0.01)$ & 0.3 & $(0.04)$ \\
\hline & 50 & 4.05 & $(0)$ & 0.28 & $(0.02)$ & 1.42 & $(0.05)$ & 0.282 & $(0.04)$ & 0.2 & $(0.01)$ & 0.27 & $(0.01)$ \\
\hline & 100 & 3.86 & $(0)$ & 0.35 & $(0.04)$ & 1.23 & $(0.03)$ & 0.265 & $(0.02)$ & 0.2 & $(0.03)$ & 0.24 & $(0.02)$ \\
\hline \multirow{3}{*}{ HER } & 25 & 3.73 & (0) & 0.19 & $(0.01)$ & 1.39 & $(0.03)$ & 0.286 & $(0.05)$ & 0.3 & $(0.02)$ & 0.25 & $(0.02)$ \\
\hline & 50 & 3.82 & $(0)$ & 0.25 & $(0.03)$ & 1.41 & $(0.14)$ & 0.301 & $(0.03)$ & 0.3 & $(0.03)$ & 0.25 & $(0.01)$ \\
\hline & 100 & 4.05 & $(0)$ & 0.38 & $(0.05)$ & 1.33 & $(0.16)$ & 0.276 & $(0.02)$ & 0.3 & $(0.02)$ & 0.25 & $(0.05)$ \\
\hline \multirow{3}{*}{ AAS } & 25 & 3.76 & $(0)$ & 0.21 & $(0.03)$ & 1.48 & $(0.15)$ & 0.312 & $(0.04)$ & 0.3 & $(0.02)$ & 0.27 & $(0.03)$ \\
\hline & 50 & 4.08 & $(0)$ & 0.25 & $(0.06)$ & 1.45 & $(0.13)$ & 0.284 & $(0.04)$ & 0.3 & $(0.03)$ & 0.27 & $(0.03)$ \\
\hline & 100 & 4.11 & $(0)$ & 0.37 & $(0.04)$ & 1.32 & $(0.23)$ & 0.288 & $(0.03)$ & 0.3 & $(0.04)$ & 0.28 & $(0.05)$ \\
\hline \multirow{3}{*}{ BER } & 25 & 3.57 & (0) & 0.17 & $(0.02)$ & 1.41 & $(0.16)$ & 0.298 & $(0.01)$ & 0.2 & $(0.01)$ & 0.25 & $(0.03)$ \\
\hline & 50 & 3.88 & $(0)$ & 0.24 & $(0.04)$ & 1.33 & $(0.24)$ & 0.26 & $(0.04)$ & 0.3 & $(0.02)$ & 0.24 & $(0.04)$ \\
\hline & 100 & 3.81 & $(0)$ & 0.35 & $(0.06)$ & 1.17 & $(0.1)$ & 0.278 & $(0.03)$ & 0.3 & $(0.03)$ & 0.22 & $(0.02)$ \\
\hline \multirow{3}{*}{ CGL } & 25 & 3.89 & (0) & 0.19 & $(0.01)$ & 1.61 & $(0.15)$ & 0.308 & $(0.02)$ & 0.3 & $(0.01)$ & 0.29 & $(0.03)$ \\
\hline & 50 & 3.82 & $(0)$ & 0.22 & $(0.01)$ & 1.36 & $(0.06)$ & 0.282 & $(0.02)$ & 0.3 & $(0.01)$ & 0.25 & $(0.01)$ \\
\hline & 100 & 3.76 & $(0)$ & 0.27 & $(0.07)$ & 1.23 & $(0.12)$ & 0.278 & $(0.03)$ & 0.3 & $(0.04)$ & 0.25 & $(0.02)$ \\
\hline \multirow{3}{*}{ XIA } & 25 & 3.85 & (0) & 0.19 & $(0.01)$ & 1.44 & $(0.05)$ & 0.292 & $(0.02)$ & 0.2 & $(0.01)$ & 0.25 & $(0.01)$ \\
\hline & 50 & 3.8 & $(0)$ & 0.25 & $(0.03)$ & 1.34 & $(0.18)$ & 0.287 & $(0.03)$ & 0.3 & $(0.02)$ & 0.24 & $(0.03)$ \\
\hline & 100 & 3.96 & $(0)$ & 0.37 & $(0.03)$ & 1.27 & $(0.15)$ & 0.282 & $(0.01)$ & 0.3 & $(0.01)$ & 0.24 & $(0.03)$ \\
\hline
\end{tabular}


Table S4.1: Nutrient quality control from XRF analysis (Experiment B). CRM used to calculate $\%$ recovery and Limit of detection (LOD) provided by Cartesian internal calibration. Plant CRM supplied from Institute of nuclear chemistry (Code: INCT-MPH-2) and Soil CRM supplied from International soil-analytical exchange (ISE) (Code: Soil ISE 921).

\begin{tabular}{cccc}
\hline & $\begin{array}{c}\text { Recovery } \\
\text { Polish Mixed Herb } \\
\%\end{array}$ & $\begin{array}{c}\text { Recovery } \\
\text { Soil ISE 921 } \\
\%\end{array}$ & $\begin{array}{c}\text { Limit of detection } \\
\left(\mathrm{mg} \mathrm{kg}^{-1}\right)\end{array}$ \\
\hline $\mathrm{P}$ & 85 & 111 & 15 \\
$\mathrm{Mg}$ & 113 & 118 & 1 \\
$\mathrm{Al}$ & 125 & 125 & 1 \\
$\mathrm{Fe}$ & 85 & 102 & 1 \\
$\mathrm{Ca}$ & 85 & 102 & 2 \\
$\mathrm{Cu}$ & 108 & 103 & 1 \\
$\mathrm{Cr}$ & - & - & 1 \\
$\mathrm{Cd}$ & - & - & 2 \\
$\mathrm{Zn}$ & 105 & 111 & 1 \\
$\mathrm{Ni}$ & 120 & 104 & 1 \\
$\mathrm{~Pb}$ & 102 & 115 & 1 \\
$\mathrm{Mn}$ & 92 & 107 & 1 \\
\hline
\end{tabular}




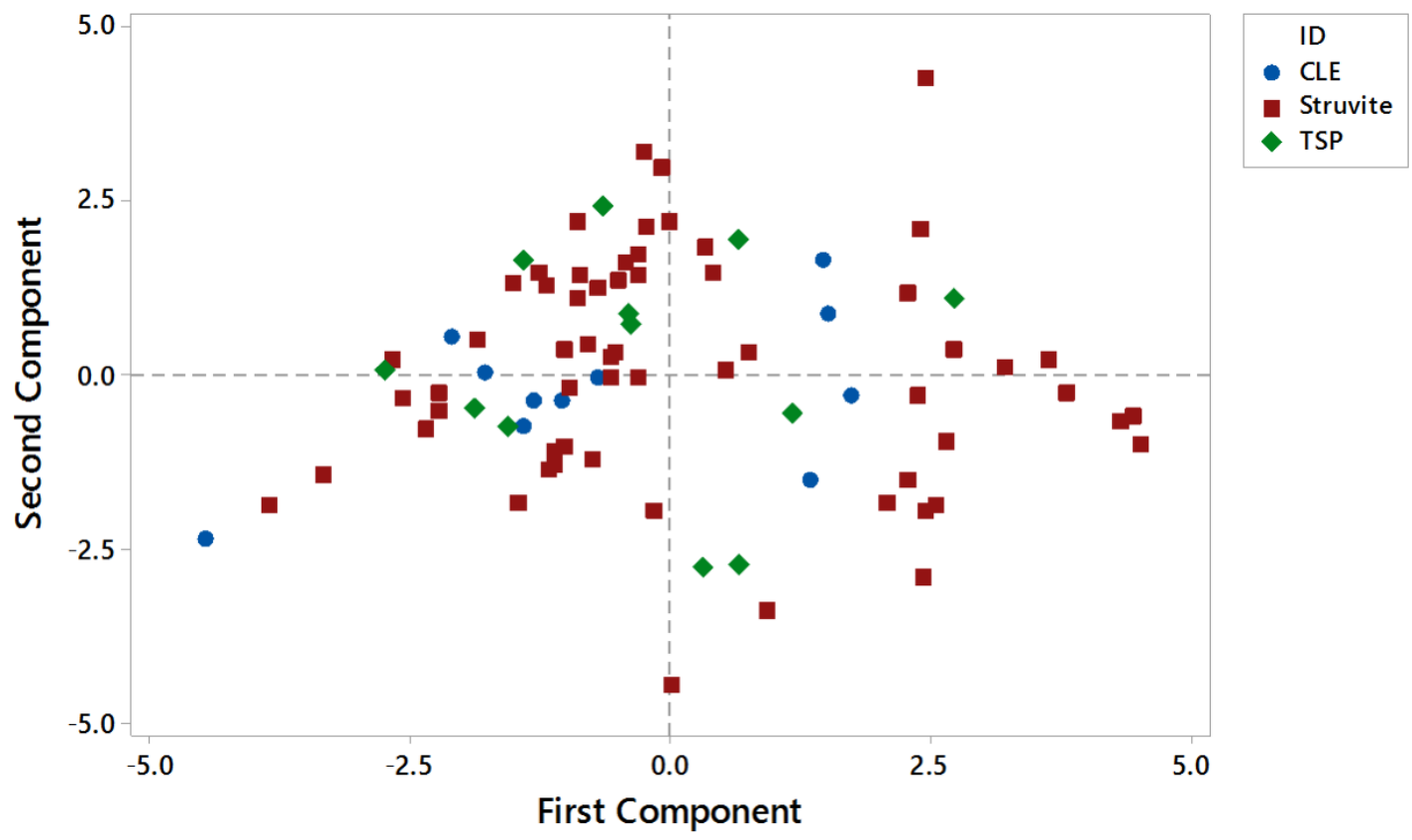

Figure S8. PCA of dry shoot matter nutrient analysis by ICP-OES. Nutrient content of harvested plant material from ICP-OES analysis available in supporting information. 


\section{S9. Quality control for the colorimetric measurements of phosphate}

Olsen P and DGT measurements of plant available P - quality control. Quality control for the Murphy and Riley molybdenum blue reagent standard solutions used for calibration were potassium phosphate monobasic $\left(\mathrm{KH}_{2} \mathrm{PO}_{4}\right)$, ammonium phosphate monobasic $\left(\mathrm{NH}_{4} \mathrm{H}_{2} \mathrm{PO}_{4}\right)$ and phosphate standard for ion chromatrography (IC) solution. All standard solutions were supplied by Sigma Aldrich and compared to a synthetic surface water certified reference materials (CRM, SPS-SW2) supplied by Spectra Pure Standards of $500 \mu \mathrm{g} \mathrm{P} \mathrm{L}^{-1}$. A calibration was conducted before a microplate was run on any individual period, after every three microplates had been analysed another calibration of $\mathrm{NH}_{4} \mathrm{H}_{2} \mathrm{PO}_{4}$ was performed to check the quality of the reading (Table $\mathrm{S} 4$ ). All samples were analysed in random order and each sample had three analytical replicates. 
Table S5: Quality control for the Murphy and Riley Molybdenum blue reagent standard solutions used for calibration were Potassium phosphate monobasic $\left(\mathrm{KH}_{2} \mathrm{O}_{4}\right)$, ammonium phosphate monobasic $\left(\mathrm{H}_{6} \mathrm{NO}_{4} \mathrm{P}\right)$ and Phosphate standard for IC solution. All standard solutions were supplied by Sigma Aldrich and compared to a synthetic surface water CRM (SPS-SW2) supplied by Spectra Pure Standards of $500 \mu \mathrm{g} / \mathrm{L}$.

\begin{tabular}{|c|c|c|c|c|c|c|}
\hline & & Olsen I & & & DGT & \\
\hline Reference & LOD & $\mathrm{R}^{2}$ & \% Recovery & LOD & $\mathrm{R}^{2}$ & \% Recovery \\
\hline Material & $\mu \mathrm{g} / \mathrm{L}$ & & (From CRM) & $\mu \mathrm{g} / \mathrm{L}$ & & (From CRM) \\
\hline $\mathrm{KH}_{2} \mathrm{O}_{4}$ & 1 & 0.99 & 97 & 1 & 0.99 & 97 \\
\hline $\mathrm{H}_{6} \mathrm{NO}_{4} \mathrm{P}$ & 1 & 0.99 & 97 & 1 & 0.99 & 97 \\
\hline IC & 1 & 0.99 & 97 & 1 & 0.99 & 97 \\
\hline
\end{tabular}




\section{SI0. Calculation of DGT measured P bioavailability}

DGT works by using a binding layer acting as an infinitive sink to accumulate solutes, overlain by a hydrogel and filter (well defined diffusion layer), and a diffusion boundary layer (DBL) to reach a steady state concentration gradient. To calculate flux, $F$, and the concentration of solute in the binding layer, $\mathrm{C}_{\mathrm{DGT}}$, (eq. 1-3);

$$
\begin{gathered}
F=\frac{M}{A t} \\
C_{D G T=\frac{\left(M-M^{\prime}\right)(\Delta g+\delta)}{D A\left(t-t^{\prime}\right)}}
\end{gathered}
$$

Where, $M$, is the mass of analyte from binding layer, $t$, is exposure time, $A$, is the exposure window of the surface gel (Davidson and Zhang, 1994). D, being the diffusion coefficient (provided by DGT Research LTD for each analyte), $\Delta g$ is the diffusion layer thickness, $\delta$, is the DBL in solution, $t^{\prime}$ and $M^{\prime}$, is the time of establishing the concentration gradient and the mass of the DBL respectively. For successful deployment of the device in solution the steady state concentration gradient in the DBL needs to be established within seconds, therefore the $t^{\prime}$ and $M^{\prime}$ ' are negligible (Davidson and Zhang, 1994, Zhang and Davidson, 1998, Davidson and Zhang, 2008) and can be simplified by equation 3 (Ding et al., 2010).

$$
C_{D G T}=\frac{M \Delta g}{D A t}
$$

Using $\mathrm{FeOH}$ as a binding agent provides a specific strong affinity for immobilising $\mathrm{P}$ in soils, sediments and fresh water and has no biochemical interference with other ions. The capacity of Ferrihydrite impregnated gels is $\leq 400 \mu \mathrm{gL}^{-1}$ (Ding el al. 2010). Table SI shows an example of DGT 
measurements in soils.

Table S6. DGT measurements in soils

\begin{tabular}{lcc}
\hline \multicolumn{1}{c}{ Soil } & $\begin{array}{c}{ }^{P} \mathrm{C}_{\mathrm{DGT}} \\
\left(\mu \mathrm{gL}^{-1}\right)\end{array}$ & Reference \\
\hline Performance of DGT in tropical soils & $4.5-440$ & Six et al (2012) \\
$\begin{array}{l}\text { 35 field trials across Southern Australia and } \\
\text { amended with TSP }\end{array}$ & $10-232$ & Mason et al. (2010) \\
\hline
\end{tabular}

\section{S11. Statistical Analysis Summary}

S7.1 Fertiliser Product solubilisation 


\begin{tabular}{lcccc}
\hline & $\begin{array}{c}\text { Degrees of } \\
\text { Freedom }\end{array}$ & $\begin{array}{c}\text { Adjusted } \\
\text { Means square }\end{array}$ & F & P \\
\hline $\begin{array}{l}\text { Struvite in HCl } \\
\begin{array}{l}\text { Struvite in HCl x } \\
\text { Precipitation Process }\end{array}\end{array}$ & 3 & 4.2761 & 0.39 & 0.00 \\
Error & 3 & 15.9 & 0.03 & 0.765 \\
$\begin{array}{l}\text { Struvite in H2O } \\
\text { Struvite in H2O x }\end{array}$ & 23 & & & \\
$\begin{array}{l}\text { Precipitation Process } \\
\text { Error }\end{array}$ & 3 & 6.000 & 3.24 & 0.027 \\
& 23 & 1.598 & 0.44 & 0.724 \\
$\begin{array}{l}\text { Solubilisation } \\
\text { Soil type }\end{array}$ & 14.953 & 3.738 & & \\
Error & 7 & 70.1 & 5.74 & 0.003 \\
\hline
\end{tabular}

S7.2 Experiment $A$

All treatments

\begin{tabular}{lcccc}
\hline & $\begin{array}{c}\text { Degrees of } \\
\text { Freedom }\end{array}$ & $\begin{array}{c}\text { Adjusted } \\
\text { Means square }\end{array}$ & $\mathrm{F}$ & $\mathrm{P}$ \\
\hline \multicolumn{1}{c}{ P offtake } & 6 & 0.3335 & 2.05 & 0.072 \\
$\begin{array}{l}\text { Treatment } \\
\text { Dose }\end{array}$ & 2 & 32.8466 & 201.96 & 0.000 \\
Treatment x Dose & 12 & 0.0820 & 0.50 & 0.904 \\
Error & 82 & & & \\
& & & & \\
\multicolumn{1}{c}{ DGT } & 6 & 0.001064 & 1.23 & 0.305 \\
Treatment & 2 & 0.040348 & 46.50 & 0.000 \\
Dose & 12 & 0.001144 & 1.32 & 0.232 \\
Treatment x Dose & 62 & & & \\
Error & & & & \\
\hline
\end{tabular}

S7.3 Without TSP/MAP 


\begin{tabular}{lcccc}
\hline & $\begin{array}{c}\text { Degrees of } \\
\text { Freedom }\end{array}$ & $\begin{array}{c}\text { Adjusted } \\
\text { Means square }\end{array}$ & $\mathrm{F}$ & $\mathrm{P}$ \\
\hline \multicolumn{1}{c}{ P offtake } & & & & \\
Treatment & 4 & 0.4340 & 2.35 & 0.068 \\
$\begin{array}{l}\text { Dose } \\
\text { Treatment x Dose }\end{array}$ & 2 & 24.6253 & 133.63 & 0.000 \\
Error & 8 & 0.1102 & 0.60 & 0.774 \\
& 45 & & & \\
\multicolumn{1}{c}{ DGT } & & & & \\
Treatment & 4 & 0.000828 & 0.87 & 0.490 \\
Dose & 2 & 0.027261 & 28.63 & 0.000 \\
Treatment x Dose & 8 & 0.000948 & 1.00 & 0.453 \\
Error & 25 & & & \\
\hline
\end{tabular}

Experiment B

S7.3 All fertiliser treatments

\begin{tabular}{|c|c|c|c|c|}
\hline & $\begin{array}{c}\text { Degrees of } \\
\text { Freedom }\end{array}$ & $\begin{array}{c}\text { Adjusted } \\
\text { Means square }\end{array}$ & $\mathrm{F}$ & $\mathrm{P}$ \\
\hline \multicolumn{5}{|l|}{ P offtake } \\
\hline Treatment & 7 & 22.6 & 1.31 & 0.288 \\
\hline Soil & 1 & 325 & 18.87 & 0.004 \\
\hline Treatment x Soil (1\&2) & 4 & 46.4 & 0.63 & 0.703 \\
\hline Error & 32 & & & \\
\hline \multicolumn{5}{|l|}{ DGT } \\
\hline Treatment & 6 & 37.1689 & 2.32 & 0.064 \\
\hline Soil & 1 & 17.2265 & 30.06 & 0.000 \\
\hline Treatment x Soil (1\&2) & 3 & 0.08973 & 0.22 & 0.723 \\
\hline Error & 35 & & & \\
\hline
\end{tabular}

